\title{
The Jartai Pass Site in Nilka County, Xinjiang
}

\section{Xinjiang Institute of Cultural Relics and Archaeology, Culture Bureau of the Ili Kazakh Autonomous Prefecture and Culture Bureau of Nilka County}

Keywords: Andronovo Culture; buildings; coal utilization-history; Jartai Pass Site (Nilka County, Xinjiang).

\begin{abstract}
In 2015 and 2016, the Xinjiang Institute of Cultural Relics and Archaeology excavated the Jartai Pass (Jirentai Goukou) Site in Nilka County, Ili Prefecture. The excavation recovered $2500 \mathrm{sq} \mathrm{m}$ in total, finding 20 house foundations and eight early burials as well as over 1000 artifacts including pottery, stone objects, and bronzes. The Jartai Pass Site was assigned to the Andronovo Culture with a date of about $3600 \mathrm{BP}$. It thus is the largest and earliest settlement site of the Bronze Age in the Ili River valley found to date. At this site, the earliest evidence for coal use in the world was found as well as evidence for bronze smelting and casting industries and iron ingots of an earlier period. This excavation provided important data for establishing the sequence of the prehistoric archaeological cultures in this area.
\end{abstract}

\section{A brief introduction}

In June 2015, the Xinjiang Institute of Cultural Relics and Archaeology conducted field research at the Jartai Pass

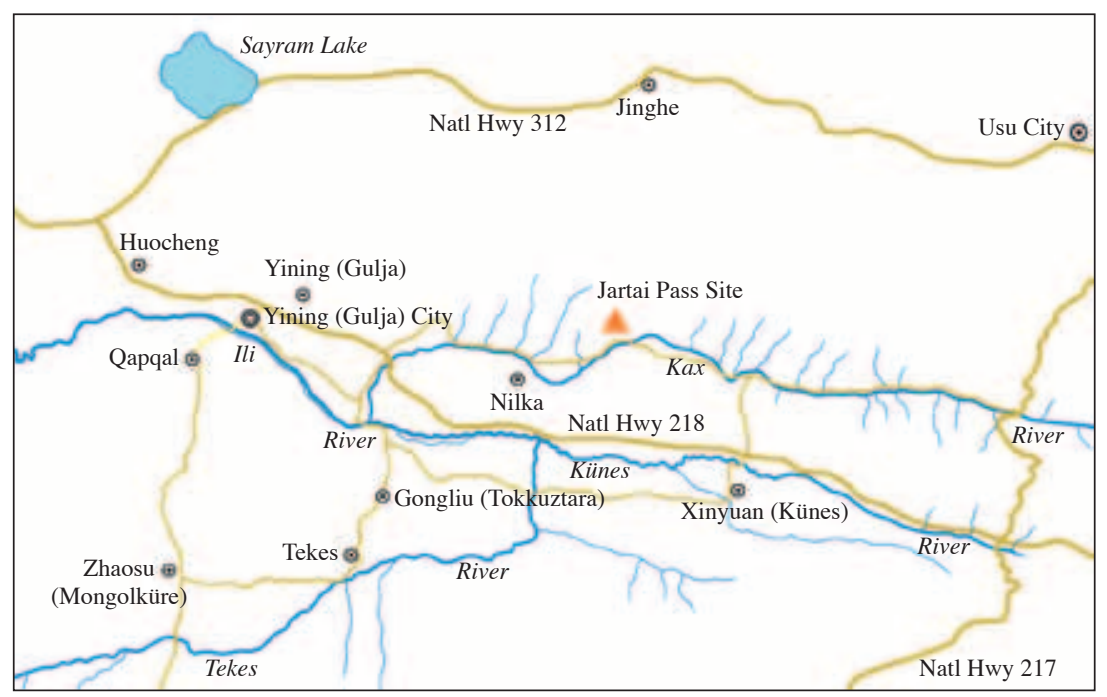

Figure 1 Map of Jartai Pass Site.
Site in Nilka County, Xinjiang, excavating burials dating from the late Bronze Age to the Song and Yuan Dynasties. During these excavations, the excavators noticed that the burials cut into an earlier settlement site, so they started excavations there, calling the site Nilka Jartai Pass Site. From July to October 2016, they conducted a second seasons of excavations at the site. During both seasons taken together, 2500sq $\mathrm{m}$ of surface area were excavated, uncovering 20 features and eight Bronze Age burials, retrieving over 1000 artifacts and artifact groups including pottery wares, stone tools, bronze, iron, and stone items. The work conducted at Jartai Pass Site meant a breakthrough in the archaeology of Ili Prefecture and is of great value to scholarly research.

\section{Geographic and environmental background}

The site is located $1.5 \mathrm{~km}$ east of the Chalger Village in the Kökxotqor Mongol Township in Nilka County (Figure 1). Located on the third terrace on the north bank of the Kax River, the locale is placed on a piedmont slope, and natural gullies divide it into five relatively flat areas. The site expands over $400 \mathrm{~m}$ from east to west and $200 \mathrm{~m}$ from north to south. Measuring about 8 ha, this is the largest Bronze Age site discovered to date in the Ili area. Enclosed by high mountains on both sides, the Kax River is on its south, the entrance to the valley is in the west, and Kax River gorge is on its eastern side. The site is thus semi-enclosed and forms a relatively independent settlement unit of considerable size. This area has a mild climate, abundant rainfall, abundant pasture land, warm temperatures and snow in winter, and cool in summers. It is suitable for grazing and provides good living conditions. Surrounded by mountains, it forms a relatively enclosed small basin with large rivers traversing it, making it easy to defend. Judging from the burials excavated at the site, the time span ranges from the Bronze Age to the Sui and Tang Dynasties, with a few burials dating as late as the Song and Yuan Dynasties. This shows that the local environment is an ideal place for people to live in (Figures 2 and 3).

\section{Stratigraphy}

The piedmont slope on which the site is located is not fully preserved but the cultural layers are relatively intact and clearly distinguishable. Some 
parts are affected by alluvial deposits and thus differ in height. Three main cultural layers can be distinguished. Layer 1 is $0.2 \mathrm{~m}$ thick and consists of dark brown loose soil containing a large number of plant roots. Layer 2 consists of yellow soil and appears throughout most of the site. The soil is relatively pure in composition but of uneven thickness, and the thickest part measures about $1 \mathrm{~m}$. There are only few cultural remains in this layer. Features opening below this layer include the houses F5, F7-F13, F16F20, and the burials M13, M20, M31, M49, M52, M72, M73, and M75. Layer 3 is grayish-yellow soil, rich in remains and relics. This layer in $\mathrm{T} 2$, $\mathrm{T} 9$, and $\mathrm{T} 12$ can be further divided into two sub-layers. Features F2, F6, F14, and F15 were observed below Layer 3A, cutting into Layer 3B. Based on stratigraphic relationships and object typologies, the site can be divided into two phases. Phase I includes the houses F1-F4, F6, F14, and F15. Phase II includes the houses F5, F7-F13, F16-F20, and burials M13, M20, M31, M49, M52, M72, M73 and M75.

\section{Features}

The main features observed at Jartai Pass Site are houses, hearths inside the houses, trash pits, postholes, and burials.

1. Houses.

The house features are the main discovery of this excavation season. Based on size, they can be divided into two types, large and small.

(1) Three large houses (F2, F4 and F6):

Each measures 100-400sq m in surface area, they are unevenly distributed throughout the site, and their function seems to have differed. These features are semisubterranean houses with wooden structures and a rectangular floor plan. The construction method consists of digging a dustpan-shaped semisubterranean foundation, constructing four walls out of stones, and building an additional stone structure by erecting long stone slabs inside the stone walls and planting wooden

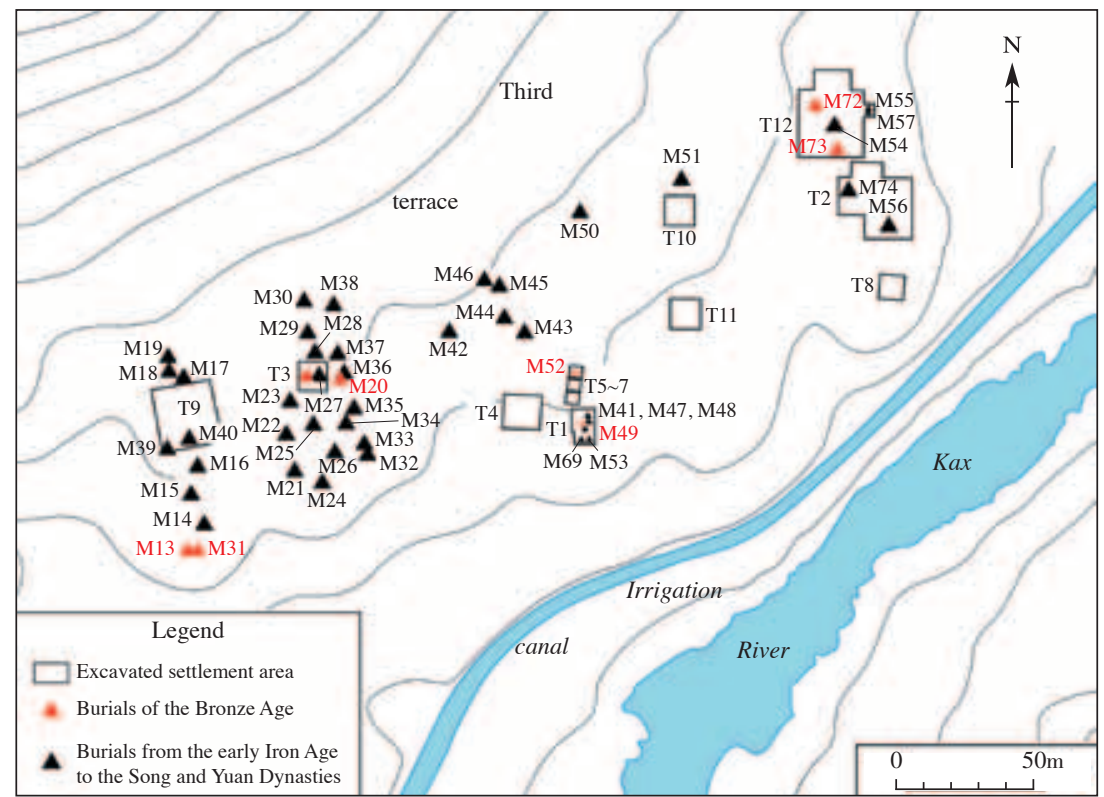

Figure 2 Map of the cemetery of Jartai Pass Site.

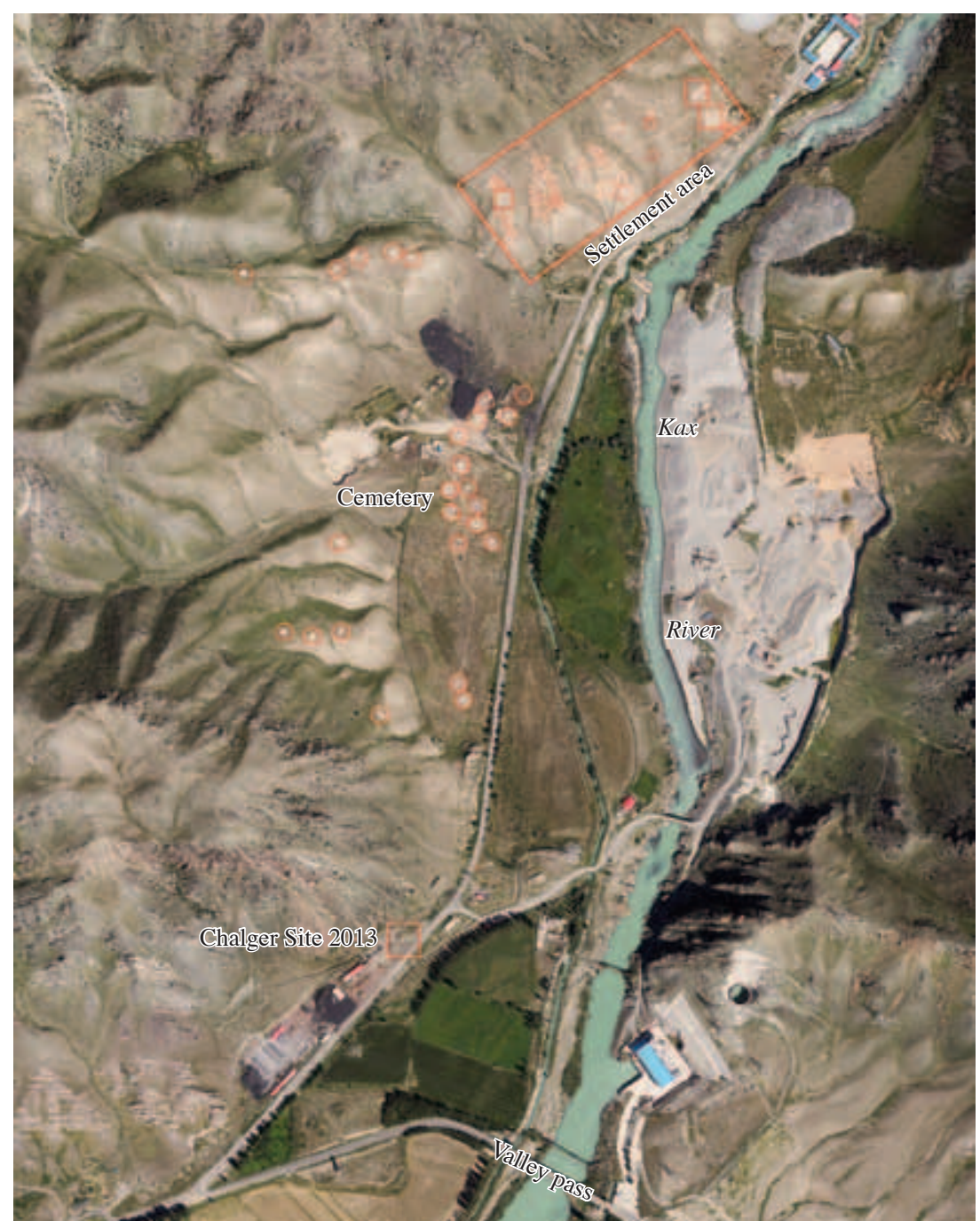

Figure 3 Jartai Pass settlement site and cemetery (top is north). 
posts to build the wall body in between. In the middle of the house, two rows of additional posts were erected to support the roof. The door faces south and a rectangular stone fireplace is located in the middle of the structure.

F6 is located in the western part of the site. It takes the highest terrain, faces south and parts of the walls are exposed on the ground surface. The house foundations are below Layer 3A, its southern part is disturbed and overlain by M40, F19, and F20. The floor plan is a northsouth oriented rectangle of $21 \mathrm{~m}$ long and $17.8 \mathrm{~m}$ wide, with an overall size of $374 \mathrm{sq} \mathrm{m}$ in general area and 240sq $\mathrm{m}$ in internal area, making it the largest Bronze Age building feature discovered to date in the Ili region (Figure 4). F6 was built on the southern hill slope, digging a dustpan-shaped semi-subterranean house foundation into the slope. The northern wall dug out of the slope was $1.1 \mathrm{~m}$ high, with both side walls descending from north to south, and built directly on the original floor level at the south. A round of retaining wall was built on the outside; the retaining walls on the east, west and south sides are well preserved, while the north retaining wall had collapsed into the house. The inside and outside of the retaining walls were built of large stones, and the core was filled with earth, resulting in a structure elevated above its surroundings, thus facilitating the flow of rain and moisture. The doorway was located in the middle of the southern wall measuring $2.3 \mathrm{~m}$ in depth and $1.8 \mathrm{~m}$ in width. On both the eastern and western walls at the $0.5 \mathrm{~m}$ mark a row of stones was inserted and there were a few postholes between wall and stones, suggesting that there had originally been a wooden wall. Inside the structure, there are thick deposits in the north and shallow ones in the south which at the northern wall can be divided into three layers. The first layer consists of loose yellowish-gray soil

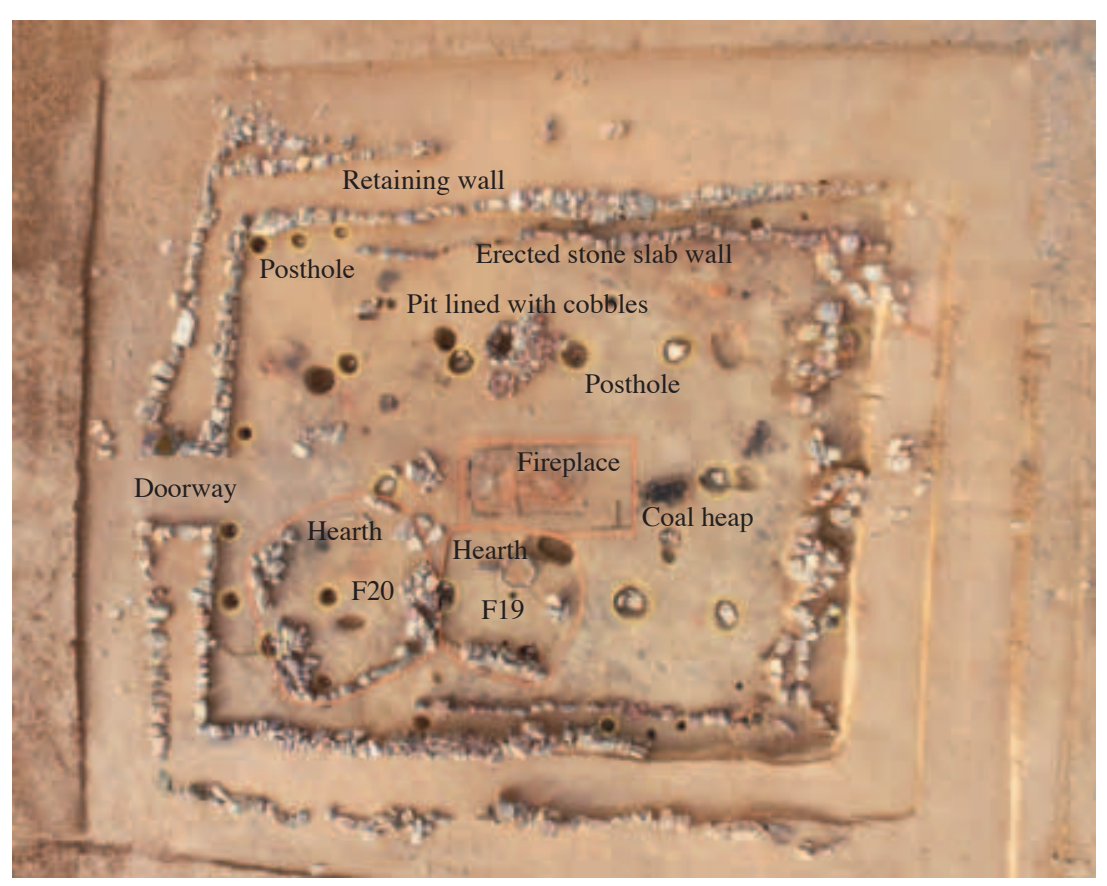

Figure 4 House foundation F6 (top is west). of $0.1-0.6 \mathrm{~m}$ thickness. It contains ash, pieces of coal and charcoal, burnt earth, stones, as well as small amounts of animal bones, potsherds, bronze and stone tools. The second layer is mainly found in the northern half. It contains mixed layers of burnt soil, charcoal, and ash. The texture is loose. There are a large number of stones near the northern wall. This layer is $0.05-0.15 \mathrm{~m}$ thick and contains large amounts of charcoal and burnt earth. There are a small number of animal bones and potsherds. The third layer is located in a relatively small area in the north, consisting of loose yellow soil with a thickness of about $0.25 \mathrm{~m}$. It contains a lot of charcoal, ash, and stones, as well as a small amount of animal bones and potsherds. The original living floor consisted of a relatively coarse yellow earth that has not been specially processed after being leveled out. In the middle of the house there was a rectangular fireplace built of erected thin stone slabs roughly forming a 日 -shaped plan. It measured $2.8 \mathrm{~m}$ in length and $1.6 \mathrm{~m}$ in width. In the fireplace, there was a large area that had been burnt brick-hard and was covered in large amounts of ash and a small amount of coal pieces and animal bones. About $2 \mathrm{~m}$ north of the fireplace, there was a heap of coal (Figure 5), and in the northwest corner of the structure another large area of coal-heaping traces and ash have been found. Around the four sides of the fireplace, 10 postholes were distributed in a symmetrical fashion with an interval of $2-3 \mathrm{~m}$ between them, probably forming the remains of the central posts of the house. The postholes were round with a diameter of $0.6 \mathrm{~m}$ and shallow with a stone at their bottoms (Figure 6). Inside the house, there were also remains of ash pits, cobble pits (Figure 7), and burnt earth surfaces. In addition, there were large areas of burnt earth, charcoal, and ash accumulations in the fill layers in the northern half of F6, as well as charcoal and charred posts that remain after the burning (Figure 8). We can thus infer that F6 had been destroyed by a large fire. After F6 had been abandoned, its southeast part was reused and two small houses were built there (F19 and F20). These features were poorly preserved and only some of the stone walls remained. F19 was roughly square and had a side length of about $4 \mathrm{~m}$. F20 was rectangular, oriented in the east-west direction, measuring $6.5 \mathrm{~m}$ in length and $4.5 \mathrm{~m}$ in width. There were round stone stoves inside these features.

F2 was located in the southeast of the site, on the eastern edge of the third terrace. The terrain is relatively low, and the Kax River flows by at the foot of the slope. The feature was located below Layer 3A, its northeastern corner was cut by F5, and it was northwest-southeast oriented. 
The structure is basically the same as that of F5 with a length of $15.3 \mathrm{~m}$, a width of $11.8 \mathrm{~m}$, and a surface area of $180 \mathrm{sq} \mathrm{m}$ (Figure 9). The retaining walls had collapsed; only the western part of the standing stone wall was well-preserved. At the base of the house feature, there were postholes; on the western wall they relatively evenly distributed and aligned in a straight line with a spacing of about $1 \mathrm{~m}$ and diameters of $0.3-0.4 \mathrm{~m}$ and depth of $0.7-0.8 \mathrm{~m}$. A flat stone base was placed on the bottom of each posthole. The doorway about $1 \mathrm{~m}$ wide was located in the center of the south wall. The living surface consisted of yellow earth, and the ground was uneven with visible trodden impressions. Due to long-term use and maintenance, the trodden surface

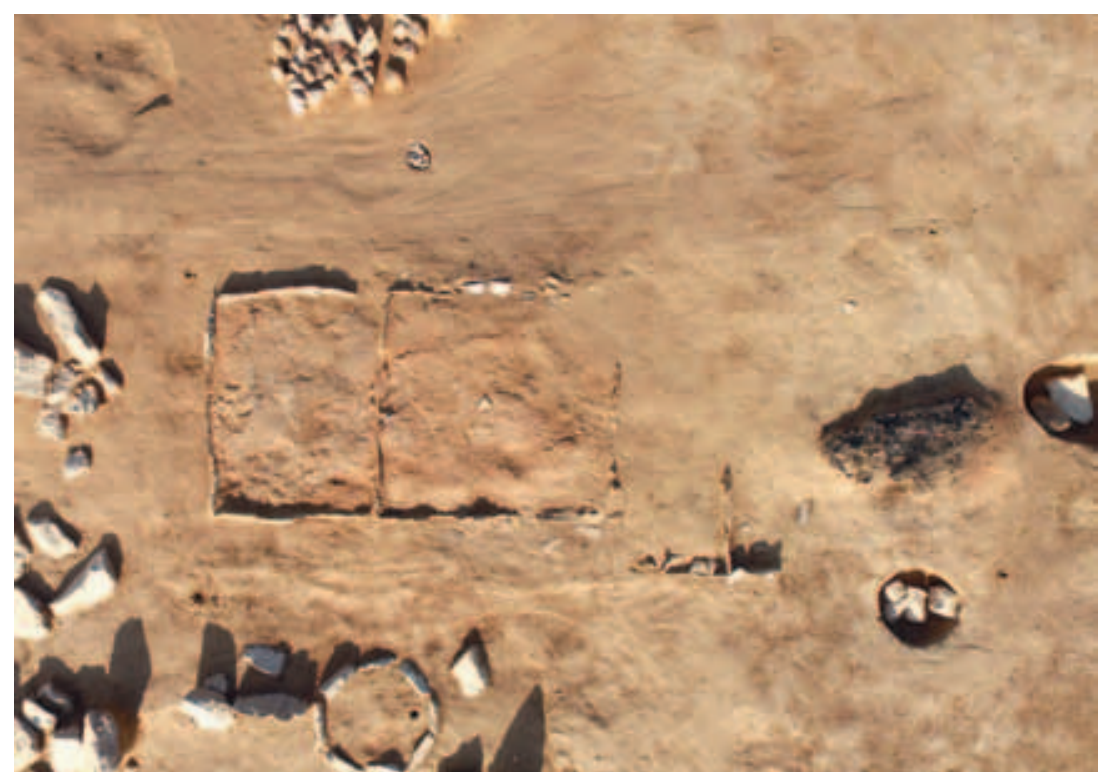

Figure 5 Fireplace and northern coal heap in house F6 (top is west).

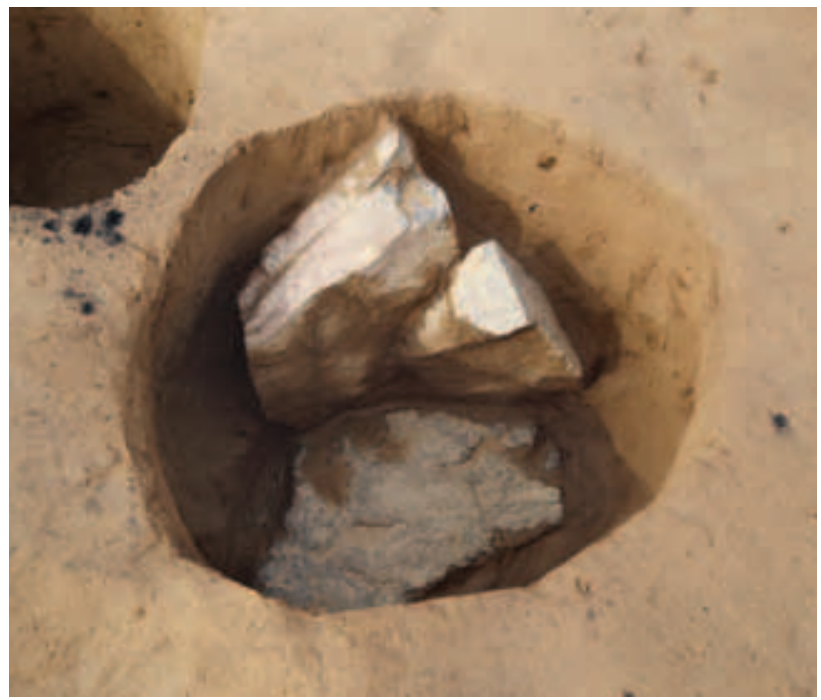

Figure 6 Posthole of house F6 (E-W).

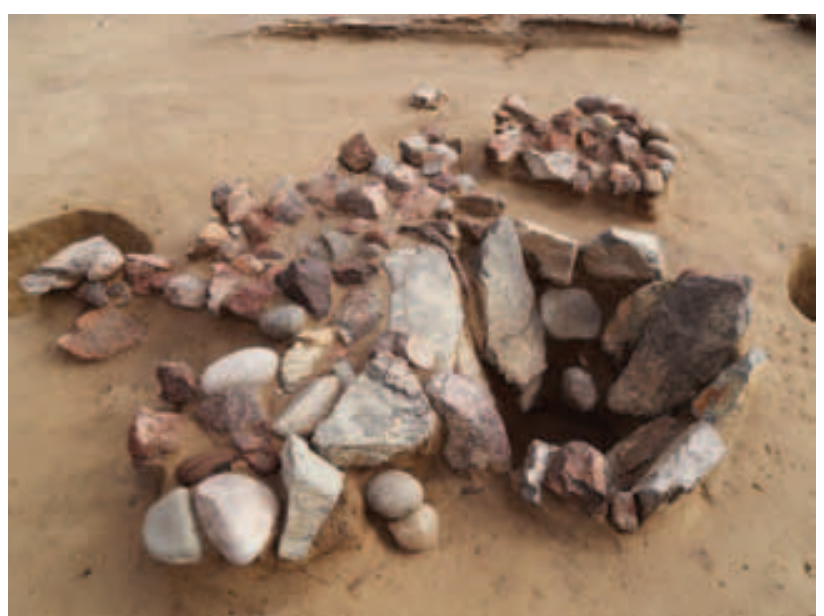

Figure 7 Pit lined with cobbles in house F6 (W-E).

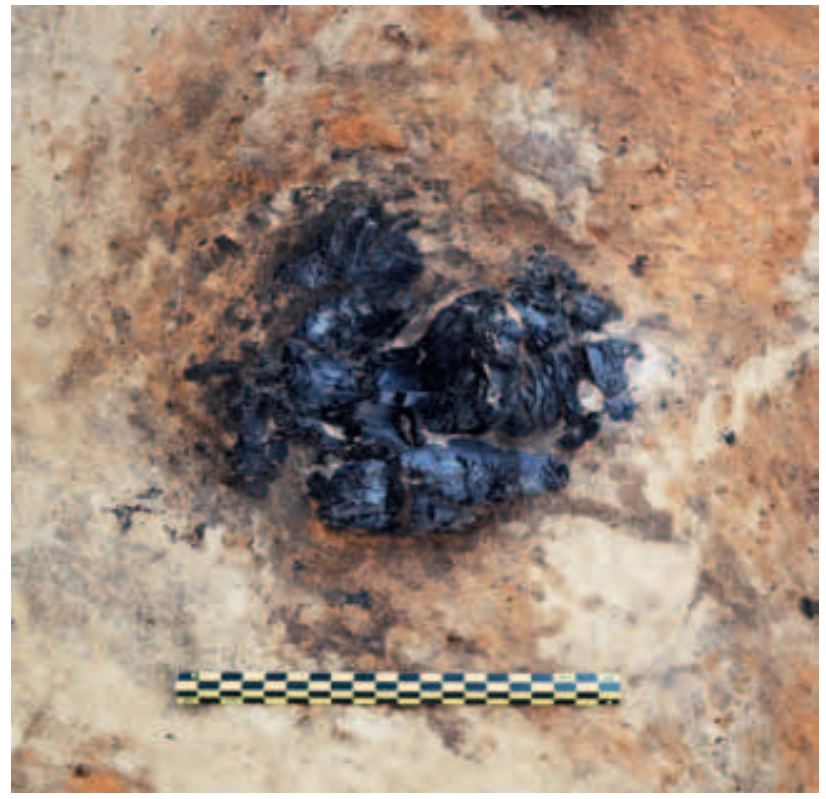

Figure 8 Charred post in house F6 $(\mathrm{S}-\mathrm{N})$.

could be divided into $2-3$ thin layers. The fireplace was located in the center and has an oval shape. It was built with elongated stones with a length of $2.25 \mathrm{~m}$ and a width of $1.75 \mathrm{~m}$ (Figure 10). There were a series of four northsouth oriented postholes about $2 \mathrm{~m}$ apart on both sides of the fire pit at a distance of $2 \mathrm{~m}$. The postholes were larger and deeper and were thus probably the remainders of the support columns of the house (Figure 11). The house contained a large number of finds as well as many burnt surfaces, such as a $3.5 \mathrm{~m}$ long and $1 \mathrm{~m}$ wide strip of burnt earth on the northern side of the fireplace. There are large ash surfaces in the southeast, southwest, northwest, and northeast parts of the house. The main remains are the ash and charcoal formed after wood has burnt out, and the 


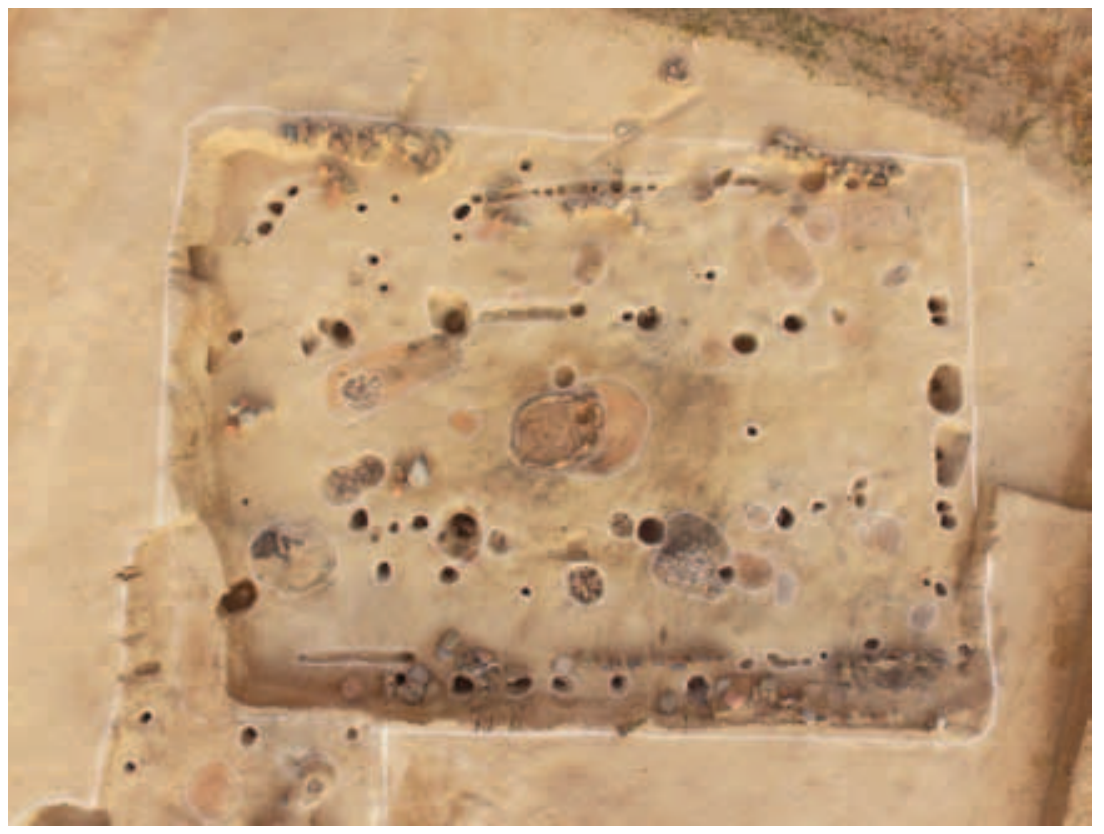

Figure 9 House F2 (W-E).

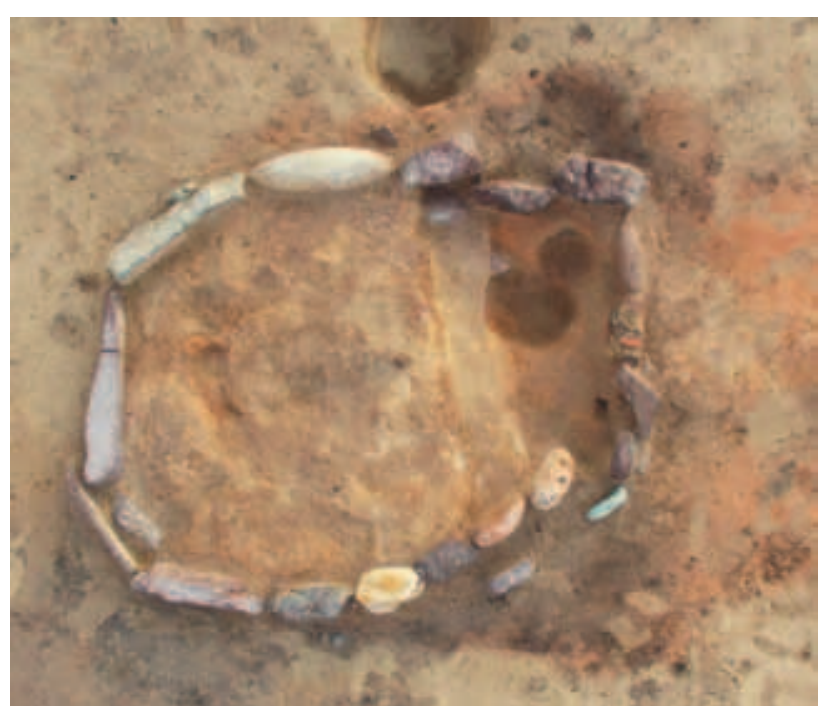

Figure 10 Fireplace in house F2 (W-E).

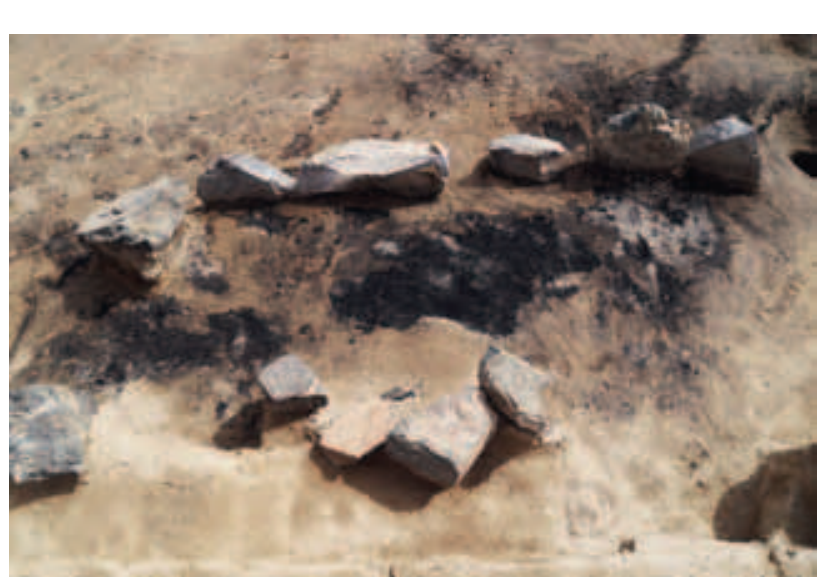

Figure 12 Raw coal heap in house F2 (W-E). bottom is hard and grayish. There are several places of raw coal heaps in the southwest corner and the northern part of the house, leaving behind either coal blocks or ash piles (Figure 12). In the north and west of the house, there are five regular stone pits of varying sizes. The larger ones measure about $0.6 \mathrm{~m}$ in diameter and $0.8 \mathrm{~m}$ in depth filled with cobbles of uniform sizes that were probably placed there after having been heated or baked, potentially for purposes of heating or preserving warmth (Figure 13). Additionally, $1 \mathrm{~m}$ outside the eastern wall a round stone hearth was found. Inside F2, there were a large number of animal bones, potsherds, stone tools, as well as bronze knives, bronze fragments, and pottery molds, some of them consisting of two parts and meant to produce mirrors, needles,

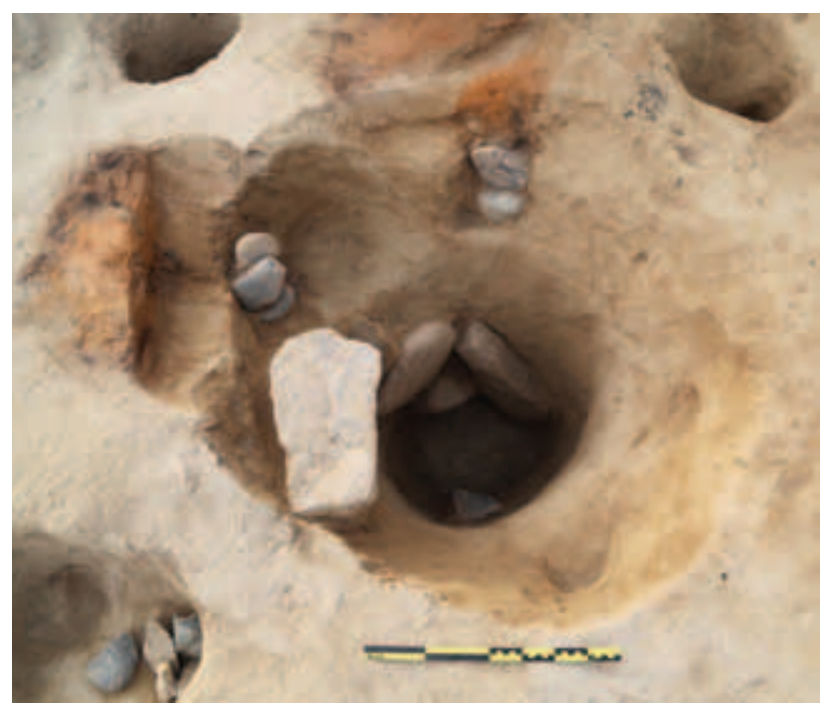

Figure 11 Posthole in house F2 (S-N).

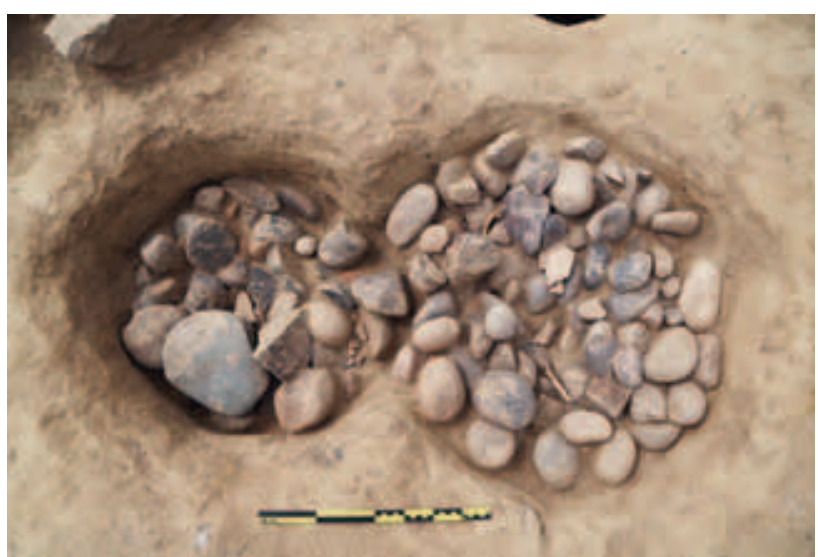

Figure 13 Pit filled with cobbles in house F2 (N-S). 
and other kinds of items.

(2) Small houses, 17 of them are recovered.

These houses mostly measure 20-60sq $\mathrm{m}$ in surface area but a few measure less than 10 sq $\mathrm{m}$. They are mainly found in the eastern part of the site below Layer 2. Eight such houses were excavated in T12 with its excavation area of $749 \mathrm{sq} \mathrm{m}$; in $\mathrm{T} 2$, five such houses were excavated, all of them clustered closely together (Figure 14). The houses are extended over several levels following the natural topography of the site. In terms of layout, several types can be distinguished, round houses and rectangular houses, as well as semi-subterranean and surface-level houses. Inside the house various features could be identified including trash pits, hearths, living surfaces, burnt areas, and cobble pits. Most houses have a circular hearth in the middle. Some of the houses were poorly preserved with only part of living surfaces without doorways and postholes remaining. Only few finds were retrieved from these features including potsherds, animal bones, and stone tools.

F15, located east of T12, lay underneath Layer 3A. It was a semi-subterranean style building of roughly rectangular floor-plan extended in northeast-southwest direction with a length of $6.5 \mathrm{~m}$ and width of $5 \mathrm{~m}$. The pit dug into the soil was irregular with a depth of $0.3-0.5 \mathrm{~m}$; the living surface was relatively even, though. Altogether 11 postholes were found in the house, mostly nearby the western and southern walls, with diameters of $0.3 \mathrm{~m}$ and depth of $0.4-0.5 \mathrm{~m}$ and stones at the bottom of each of the postholes. Two of the postholes had wooden posts in diameter of $10 \mathrm{~cm}$ and $0.16 \mathrm{~m}$ above the living surface. The heath was located in the middle of the house and it was constructed of yellow soil building an oval structure of $0.16 \mathrm{~m}$ thickness with an opening on the southern side for removing ash. The doorway was located in the middle of the southern wall and it was superimposed by a second layer of building foundations that have not yet been fully excavated (Figure 15). In addition, four small trash pits were found inside the house.

F16, located north of T2 and below Layer 2, was a semi-subterranean house of roughly rectangular shape with a surface area of $5 \mathrm{sq} \mathrm{m}$, making it the smallest building found to date in the excavation area (Figure 16). The doorway consists of a small sloped section in the eastern part connected to an east-west running small path. Inside the house, an ash pit, a hearth, and a kiln have been discovered.

Judging from the size, location, associated items and internal structures, F6 and other large buildings may have been gathering or meeting places or locales for object production or food processing. F15 and other small houses may have been living spaces.

2. Burials.

A total of eight burials of Bronze Age date were found underneath Layer 2. The burials were small in size and distributed in a scattered manner and had no mounds. The grave structures were vertical pit graves or stonecist graves. The burial style and the funeral customs were largely uniform, consisting of flexed on side position and few grave goods.

M49 cuts into the floor of F1, was located $0.3 \mathrm{~m}$ west of the Song and Yuan burials, $0.1 \mathrm{~m}$ to the southeast of the heath of $\mathrm{F} 1$, and was oriented at $235^{\circ}$. The grave shape was oval and oriented in east-west direction. It was filled

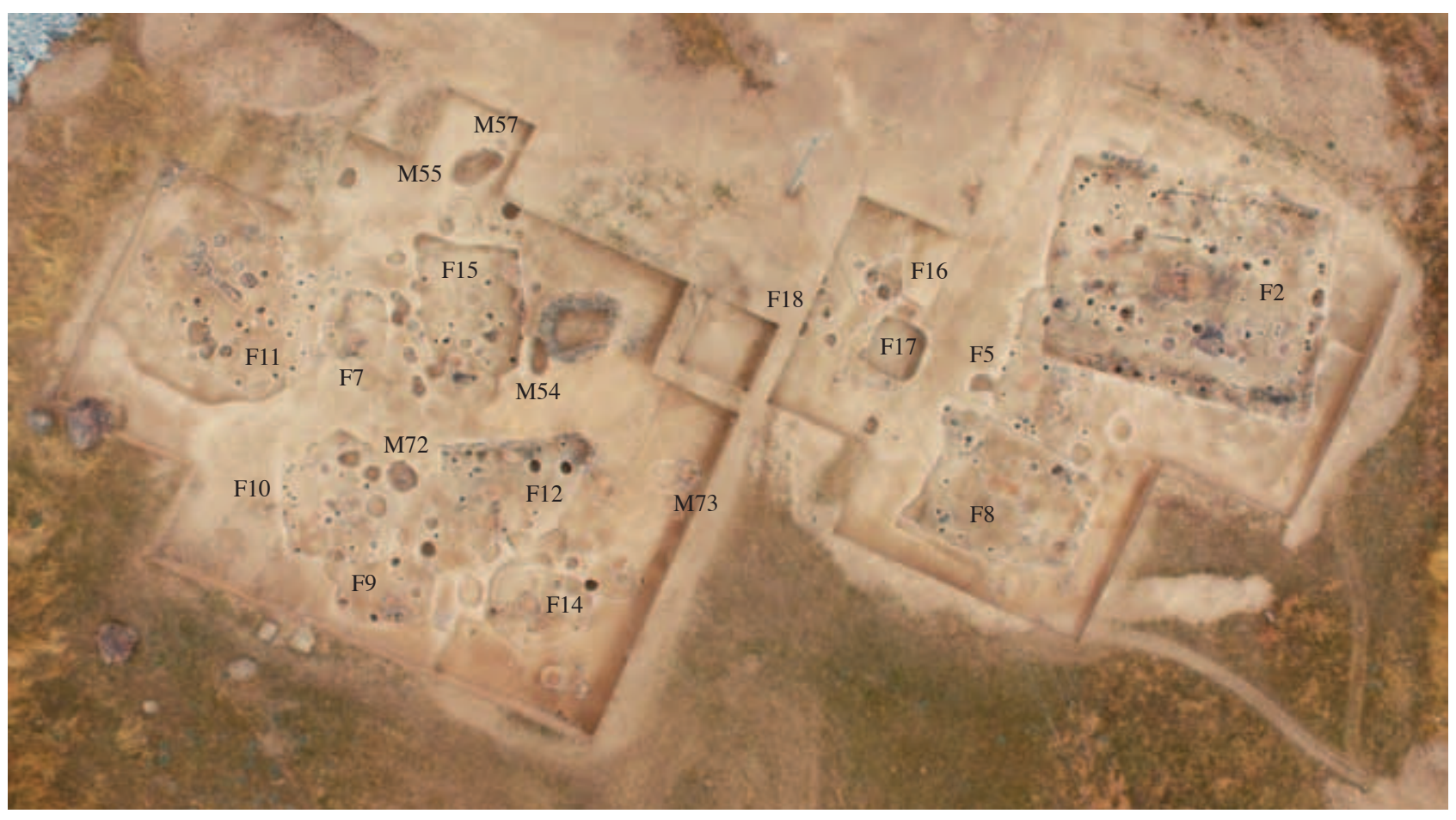

Figure 14 Features in excavation grids T2 and T12 (W-E). 


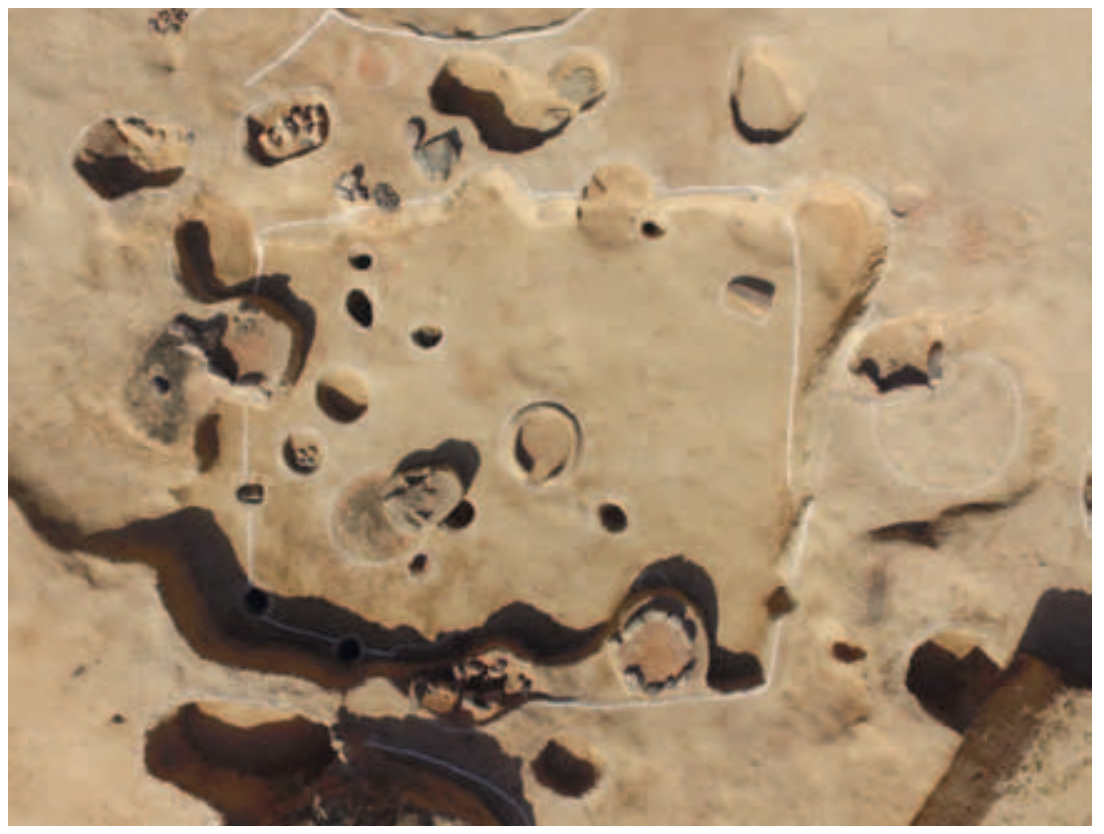

Figure 15 House F15 (S-N).

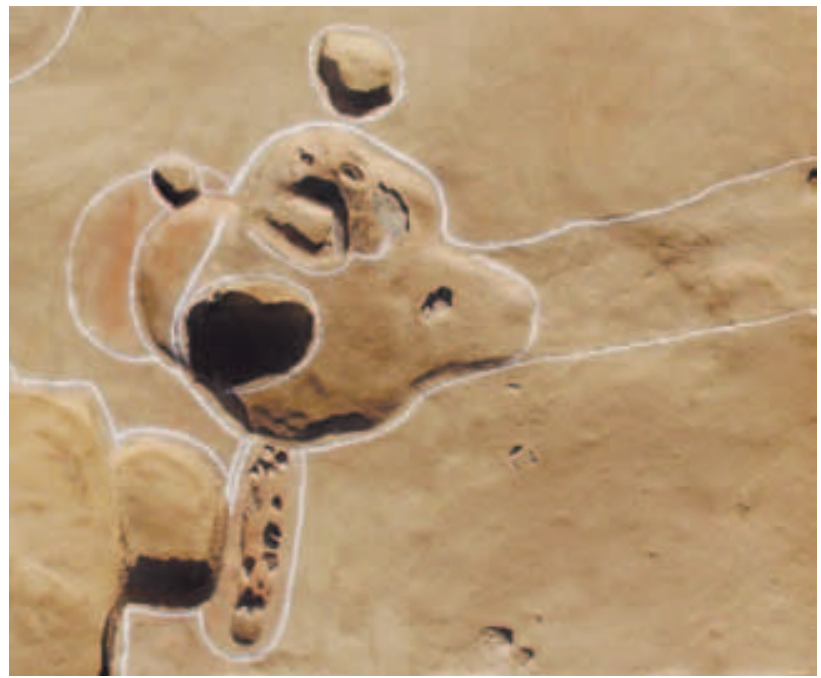

Figure 16 House F16 (S-N).

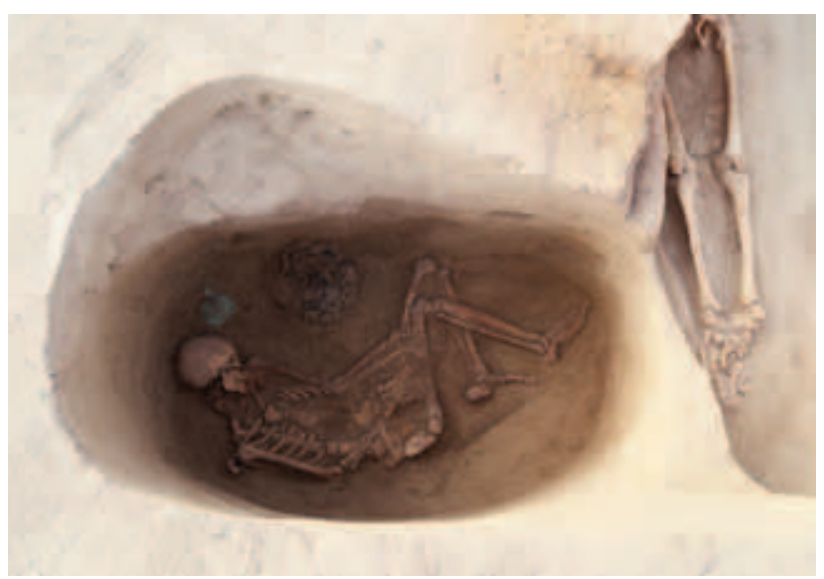

Figure 17 Burial M49 (S-N). with loose yellow soil containing pebbles arranged in an unordered fashion. A stone layer consisting of thin slates and flat pebbles occurred at a depth of $0.8 \mathrm{~m}$. Underneath the stone layer there was a yellow soil layer of $0.2 \mathrm{~m}$ thick, and the human bones were located underneath the yellow soil. It was a single primary interment in the position of flexed on left side with the head in the west, the feet in the east, and the hands on the legs. The grave goods-one bronze mirror and one pottery jar-were placed in the northwestern part of the grave (Figure 17).

M72 cuts into the southeast corner of F10 and is oriented at $126^{\circ}$. It is oval in shape with straight walls and a flat bottom. The grave was filled with loose yellow soil containing charcoal particles, ash, and a small amount of animal bones. A young woman was buried in the northeast part of the grave in a single primary interment. The body was in flexed on left side position with the head in the southeast and part of the vertebrae and ribs displaces toward the north. A string of glass beads was wound around the right wrist. Below the skeleton on the left side of the grave there was a $5 \mathrm{~cm}$ thick layer of ash with a large number of ash and charcoal in it and the ground and walls of the grave were covered in red-burnt earth (Figure 18).

M73 was cutting into Layer 3 and the primary soil and was disturbed by $\mathrm{H} 25$. It was oriented at $87^{\circ}$ with an oval floor plan. The grave was filled with loose yellow soil containing many stones. There was a stone cist in the grave which was made up of 2-3 layers of stones but without a cover. Inside the stone cist there was a single body of a young male lying on his left side, the left leg

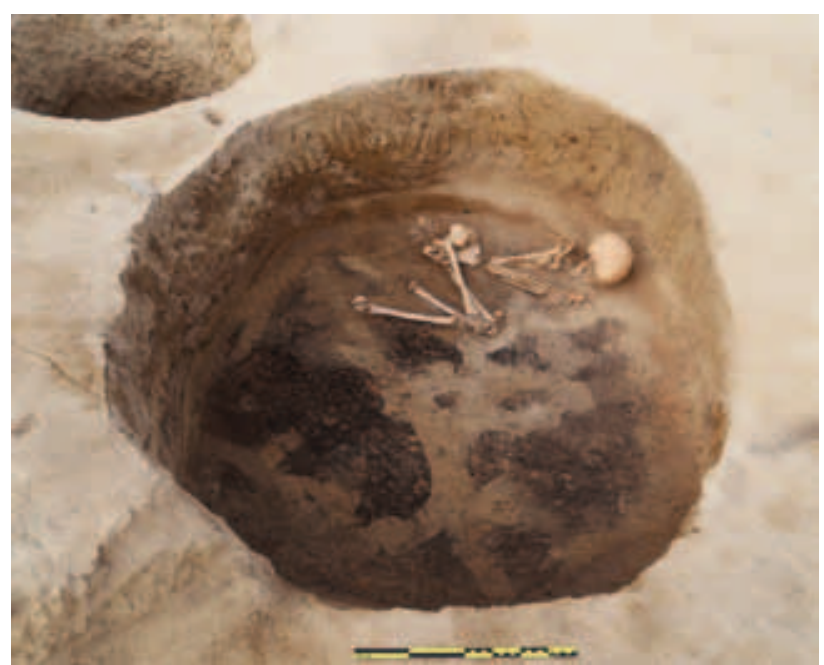

Figure 18 Burial M72 (S-N). 
bent, the right leg extended, the two feet touching the cist walls, the two hands on the chest, the head in the east, the face turned to the south. The skull was broken, the left sphenoid bone was located by the lower jaw, and the occipital bone lay by the left knee. The right 7th and 8th ribs were fused into one unusually wide bone pointing to an illness. In addition, in the area of the left abdomen, the arm and hand bones of another person were found but no further bones or grave goods (Figure 19).

\section{Unearthed artifacts}

A total of more than 1000 pieces (sets) of artifacts have been unearthed, with pottery and stone tools making up the majority of finds, accompanied by a small amount of bronzes, bone implements, and iron tools, and a large number bones of sheep, cattle, horses, and other animals.

1. Pottery wares.

Only very few pottery wares were complete or could be restored; the majority of finds were potsherds, most of which were sandy gray pottery with small amounts of sandy red ware. The pottery wares were hand-built and of a loose quality but fired at a high temperature with uneven wall thicknesses. The main identifiable vessel forms are jars, cups, and bowls. Most of them are flat-bottomed but the later period sees some round-bottomed vessel. The majority of vessels were plain, but some sherds showed incised or impressed decors, mostly on the rims or the upper parts of the bodies, mostly in the form of parallel line incisions, bosses, nail impressions, slanted line geometric patterns and the like.

Among jars, several types can be distinguished, mainly flat-bottomed jars with slanted shoulders, flat-bottomed jars with round bodies, and round-bottomed roundbodied jars. In Phase I represented by F1-F3 and F6, flatbottomed jars with sloped shoulders were popular but also small amounts of flat-bottomed round-bodied jars appeared. The flat-bottomed jars with sloped shoulders have flared mouths and angular or rounded downwardsloping shoulders, flat bottoms or a false ring foot, and simple designs or mostly no decoration at all. In Phase II represented by F5, F8, and F11, flat-bottomed roundbodied jars were popular and flat-bottomed jars with slanted shoulders appeared more rarely, and additionally round-bottomed round-shouldered jars started appearing. Flat-bottomed round-shouldered jars have wide openings, contracted necks, slanted bellies, with an overall form differing markedly from the vessels of Phase I, especially in the contracted neck, wider belly, and lobed rim. Decoration patterns include impressed patterns, incised patterns, protrusions pressed out from the inside, and other kinds of addition. Round-bottomed wide-bellied jars have a round bottom, tubular spout, and band handles as main features.

The flat-bottomed sloped-shoulder jar F1:1 is made of sandy brown ware, has a straight opening, angular rim, constricted neck, and rounded shoulders, with a rim diameter of $29 \mathrm{~cm}$, a bottom diameter of 15.2 , and a height

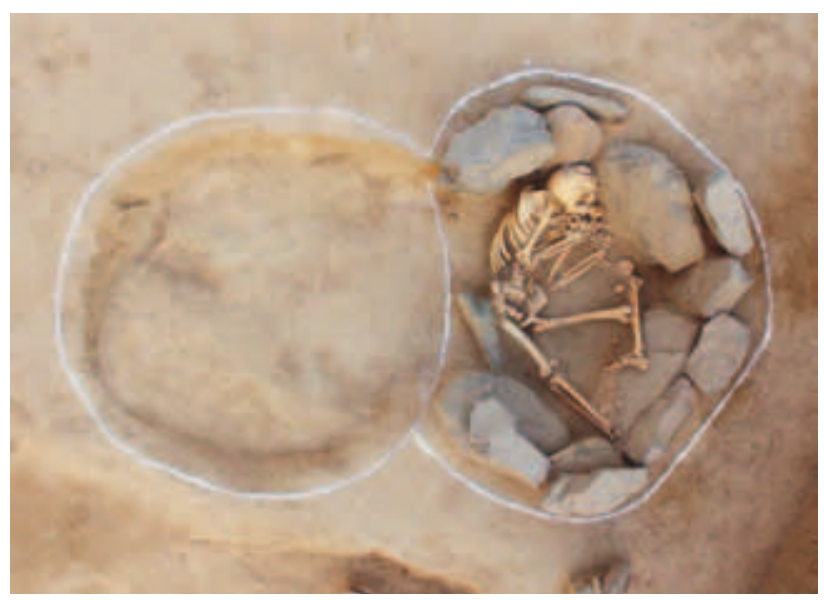

Figure 19 Burial M73 (SW-NE).

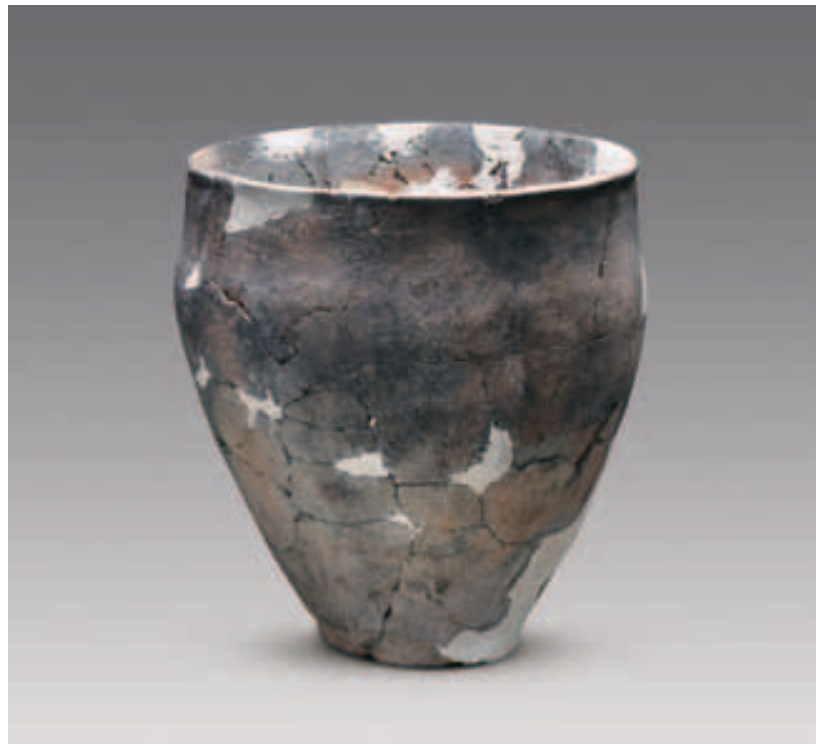

Figure 20 Flat-bottomed pottery jar with sloping shoulders (F1:1).

of $31 \mathrm{~cm}$ (Figure 20). H7:1 is made of sandy gray ware, with a flared opening, round lip, contracted neck, round shoulders, and small flat bottom. There are three parallel horizontal incised lines in the neck and shoulder areas. The rim diameter is $22.5 \mathrm{~cm}$, the bottom diameter is $9 \mathrm{~cm}$, and the height is $13.5 \mathrm{~cm}$ (Figure 21).

The flat-bottomed round-bodied jar F3:1 is made of sandy brown ware, has a straight opening, short contracted neck, and sloping shoulders. The rim is lined with an appliqué band with impressed pattern and on the shoulder there is a row of impressed bosses. The rim diameter is $29.8 \mathrm{~cm}$, the bottom diameter is $14 \mathrm{~cm}$, and the height is $35.6 \mathrm{~cm}$ (Figure 22).

T12 (3) :24 is made of sandy brown ware, has a small outward-flaring opening, contracted neck, sloping shoulders, large round body, and small flat bottom. The neck and shoulders are marked with a row of overturned triangular incisions with line incisions inside them. The 
rim diameter is $13.3 \mathrm{~cm}$, the bottom diameter $10.8 \mathrm{~cm}$, and the height $33.8 \mathrm{~cm}$ (Figure 23). T12 (3):47 is made of sandy red ware, has a small outward-flaring opening, contracted neck, and sloping shoulders. Its rim diameter is $10.2 \mathrm{~cm}$, the bottom diameter is $10 \mathrm{~cm}$, and the height $23 \mathrm{~cm}$ (Figure 24).

Round-bottomed round-bellied jars were mainly found in T12. Most have a tubular spout, band handles, and pronounced rim. A completely preserved object like this was found in the southern part of the burial mound of M4 (C:2). It is made of sandy gray ware, has a small outward-flaring opening, round lip, short neck, round belly, and round bottom. The neck is decorated with a row of impressed round dots. On the upper belly there is

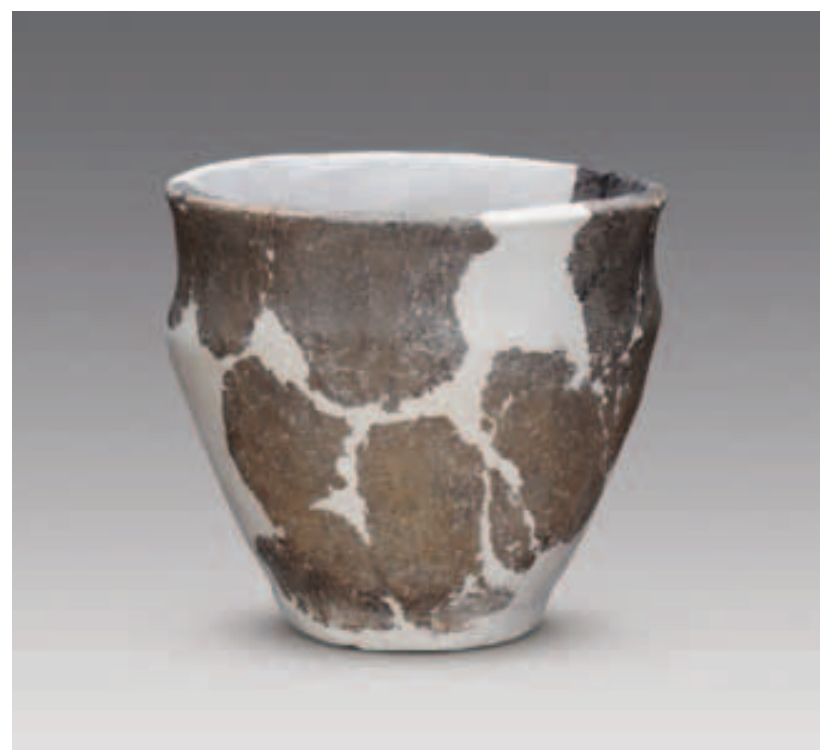

Figure 21 Flat-bottomed pottery jar with sloping shoulders (H7:1).

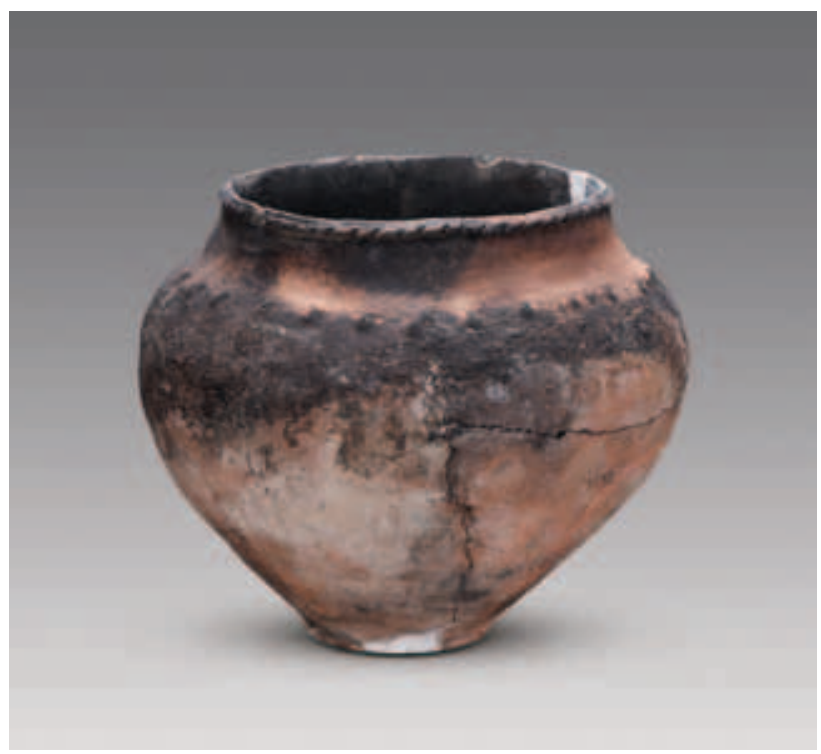

Figure 22 Flat-bottomed pottery jar with round shoulders (F3:1). a tubular spout and a pair of unevenly sized band handles. The spout opening is oval, which is $8.4 \mathrm{~cm}$ in major diameter and $7.3 \mathrm{~cm}$ in minor diameter. The small band handle is located below the tubular spout, the large band handle is on the opposite side of the vessel on the upper part of the belly, and the surface is decorated with three round dots. The surface furthermore shows soot traces. The rim diameter is $29.4 \mathrm{~cm}$, the maximum belly diameter is $35.4 \mathrm{~cm}$, and the height is $22.4 \mathrm{~cm}$ (Figure 25 ).

The cups are small in size, made of sandy gray ware, have a tubular shape, straight opening, round or angular lip, slanted or curved shoulders, and flat bottom. They are undecorated. T12 (3):63 has a round lip and slanted shoulders, a rim diameter of $3.3 \mathrm{~cm}$, a bottom diameter

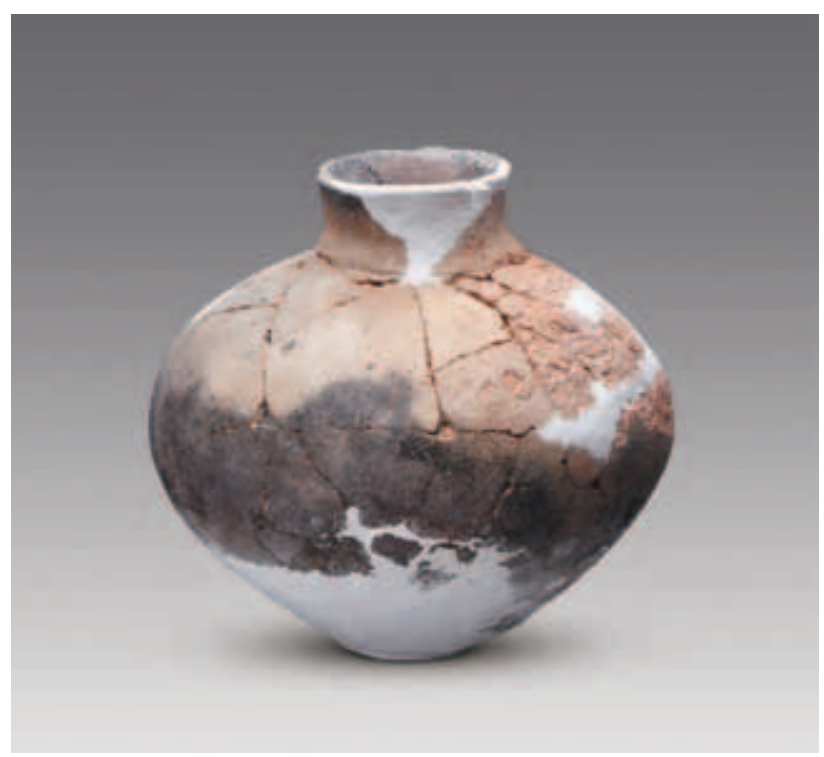

Figure 23 Flat-bottomed pottery jar with round shoulders (T12 (3) :24).

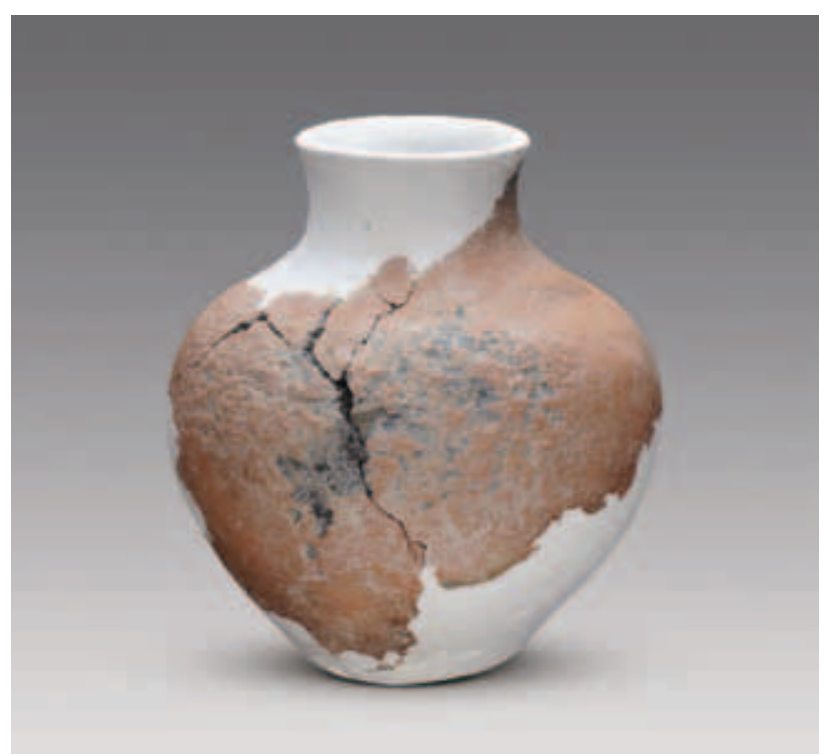

Figure 24 Flat-bottomed pottery jar with round shoulders (T12 (3) :47). 
of $2 \mathrm{~cm}$, and a height of $2.6 \mathrm{~cm}$ (Figure 26). F3:5 has an angular lip, curved wall, a rim diameter of $4.4 \mathrm{~cm}$, bottom diameter of $3.6 \mathrm{~cm}$, and height of $3.8 \mathrm{~cm}$ (Figure 27).

The shallow bowls are made of gray coarse ware with a straight opening, short spout, shallow body, and flat bottom. F6: 10 is $7.6 \mathrm{~cm}$ long, $5.1 \mathrm{~cm}$ wide, and $2.1 \mathrm{~cm}$ high (Figure 28:left). F5:1 is $6.8 \mathrm{~cm}$ long, $5.1 \mathrm{~cm}$ wide, and $2.5 \mathrm{~cm}$ high (Figure 28:right).

The spindle whorls are made of sandy red ware, have a round shape and a single hole in the middle. F6:9 has a diameter of $4 \mathrm{~cm}$, a hole diameter of $0.8 \mathrm{~cm}$, and a height of $1.1 \mathrm{~cm}$ (Figure 29). T4 (3):3 has an outer diameter of $4.4 \mathrm{~cm}$, a hole diameter of $1 \mathrm{~cm}$, and a thickness of $0.7 \mathrm{~cm}$ (Figure 30).

The molds are made of fine clay fired at high temperatures to a hard consistency. F2:10 is of brick-red color, rectangular in shape with four conical recesses in the front and an irregular back. The sides have grooves for binding the molds together. This is probably one of two parts of a two-part mold for casting bronze awls. It

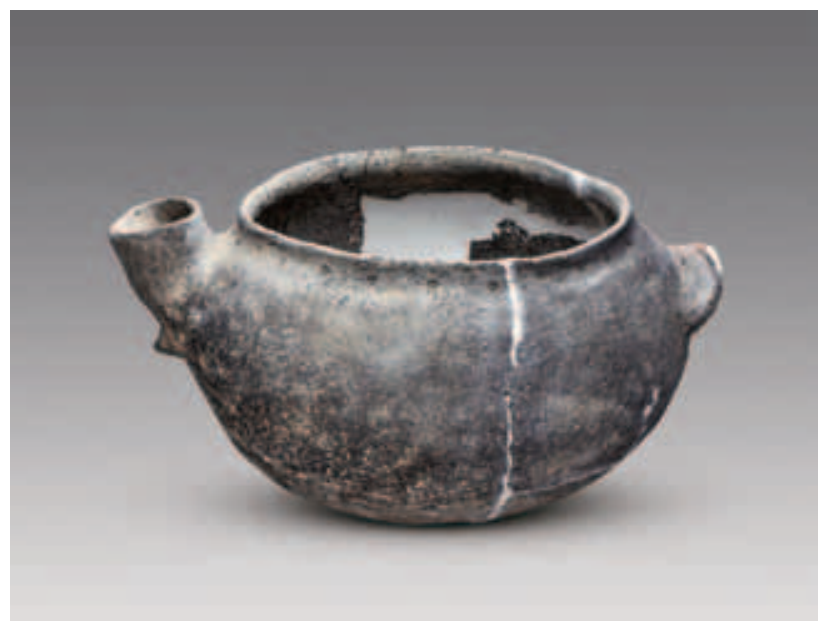

Figure 25 Round-bottomed pottery jar with round shoulders (C:2).

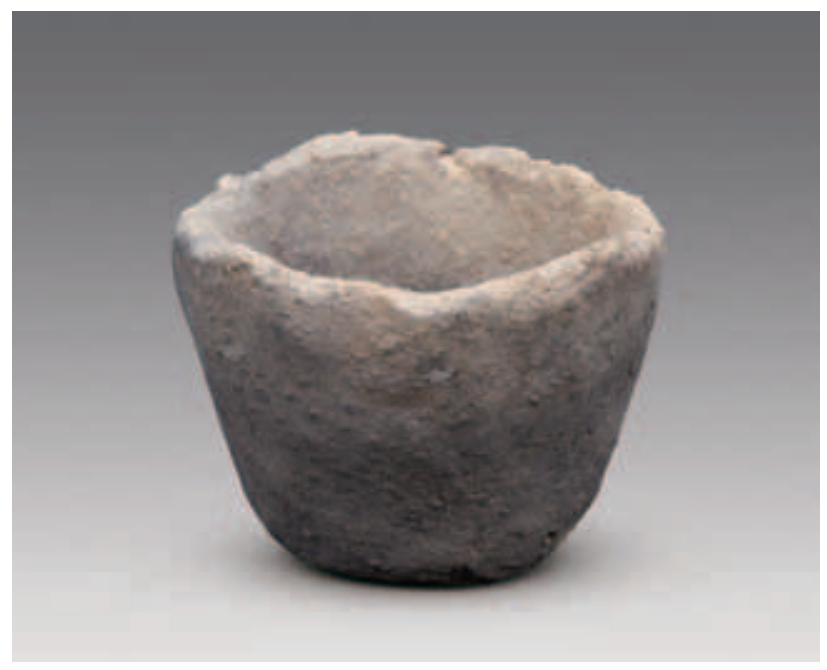

Figure 26 Pottery cup (T12 (3):63). is $8.7 \mathrm{~cm}$ long, $6.3 \mathrm{~cm}$ wide, and $4 \mathrm{~cm}$ thick (Figure 31 ). F2:11 could be restored and was probably meant to cast a mirror and awl. The color of the form is bright yellow, the shape is rectangular with small grooves and scratches on both sides. The mold is $12 \mathrm{~cm}$ long, $9.8 \mathrm{~cm}$ wide, and 4.4 thick (Figure 32).

2. Stone implements.

The stone implements were mainly made from river pebbles. They include querns, pestles, shovels, adzes, and staff heads.

Quern F6:26 is rectangular, slightly curved on both ends, and both sides are largely flat. It is $27 \mathrm{~cm} \mathrm{long,} 10 \mathrm{~cm}$ wide, and $1 \mathrm{~cm}$ thick (Figure 33).

Pestle F6:17 is a ground and polished stone tool made from a long sandstone piece. The top is in the shape of a stupa and the lower part cylindrical. It is $28 \mathrm{~cm}$ long with a maximum diameter of $8 \mathrm{~cm}$ (Figure 34). F6:31 is of square prismatic shape, made by polishing and with traces of wear on both ends. It is $12.2 \mathrm{~cm}$ long and $4 \mathrm{~cm}$ wide (Figure $35)$.

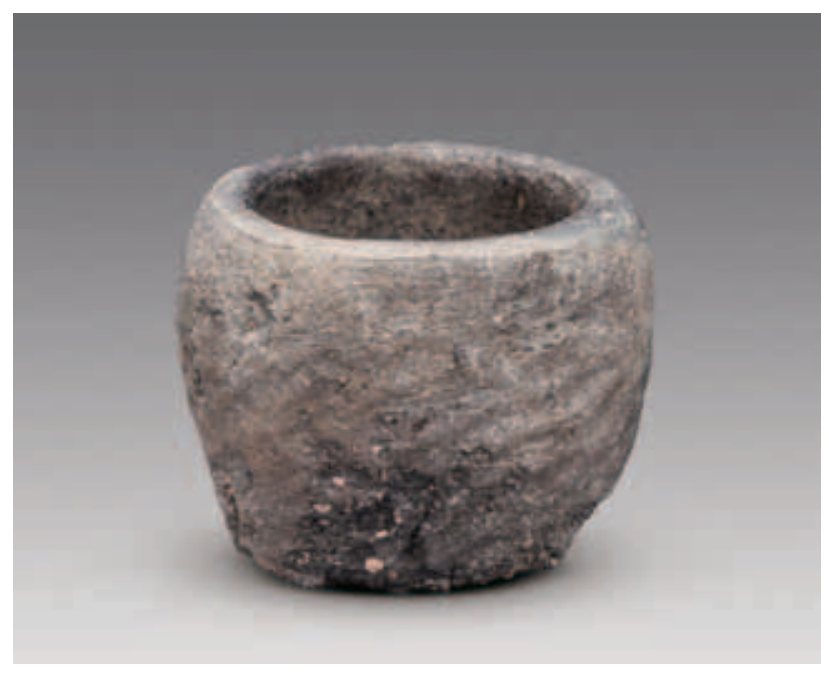

Figure 27 Pottery cup (F3:5).

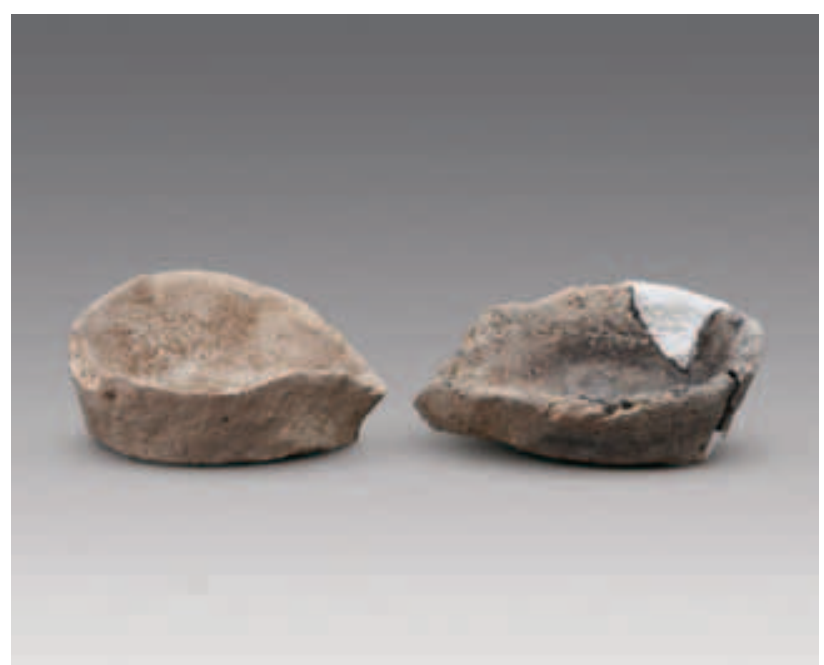

Figure 28 Shallow pottery bowls (Left. F6:10; right. F5:1). 


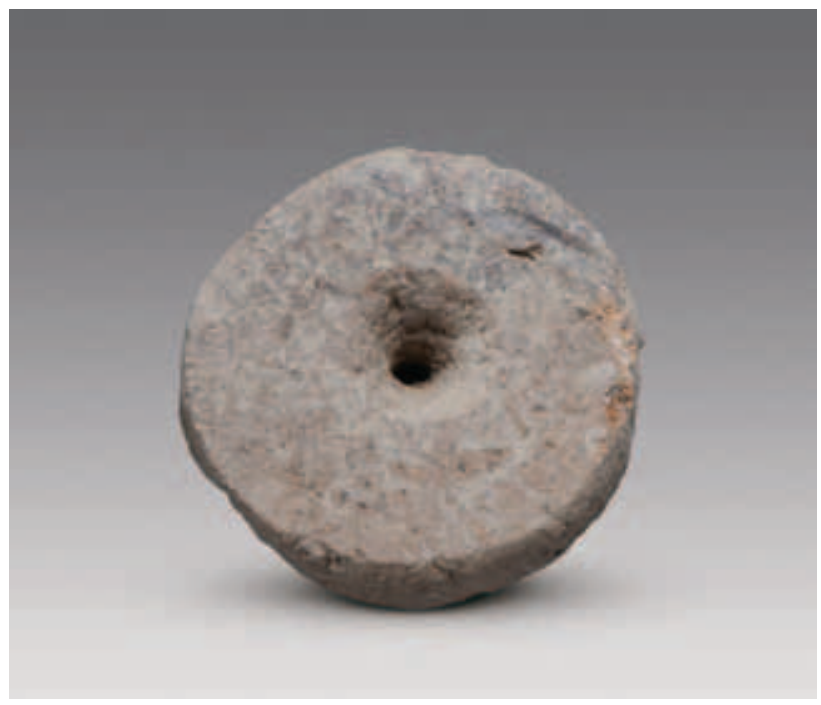

Figure 29 Pottery spindle whorl (F6:9).

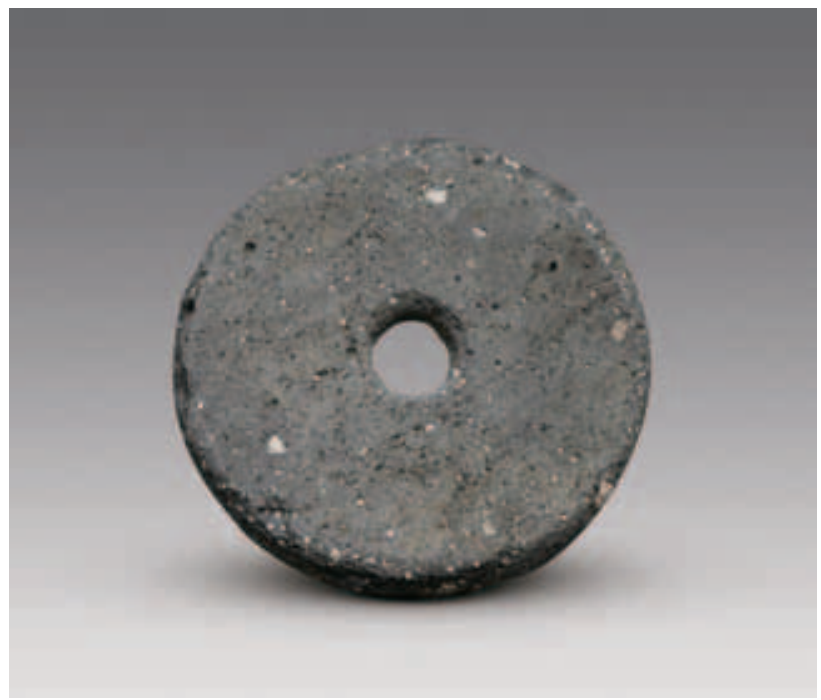

Figure 30 Pottery spindle whorl (T4 (3) :3).

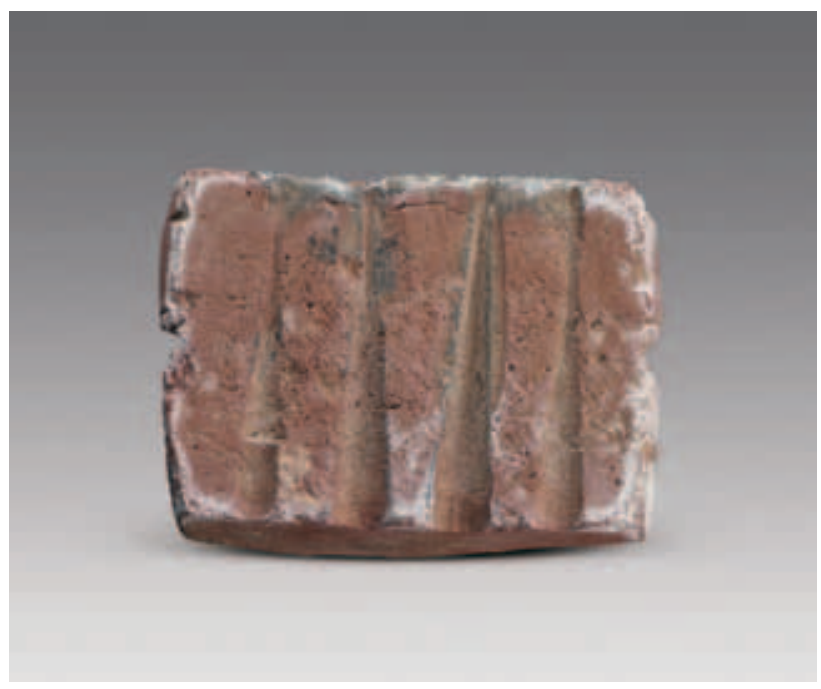

Figure 31 Pottery mold (F2:10).

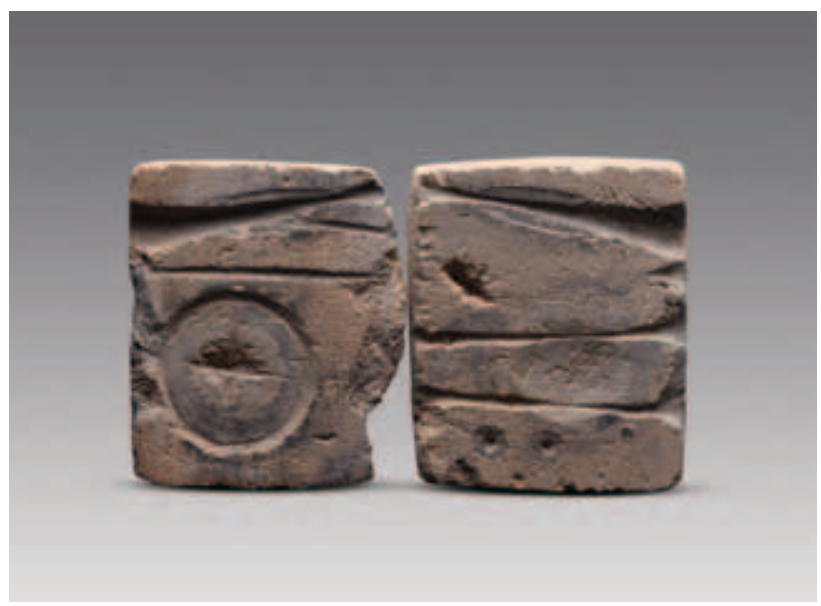

Figure 32 Pottery mold (F2:11).

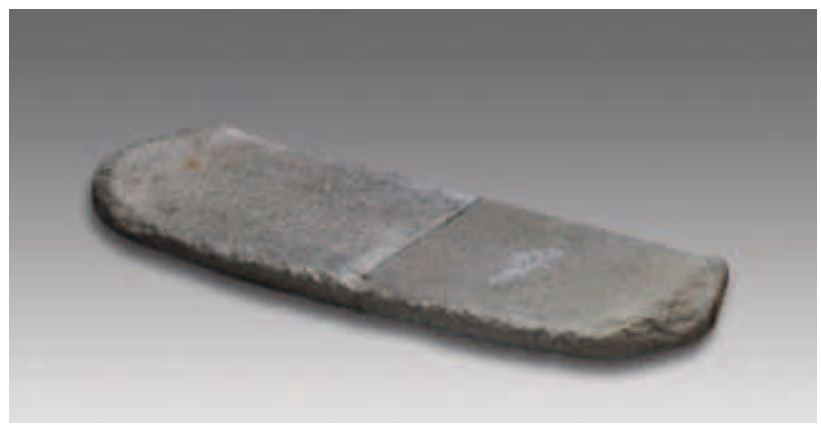

Figure 33 Stone quern (F6:26).

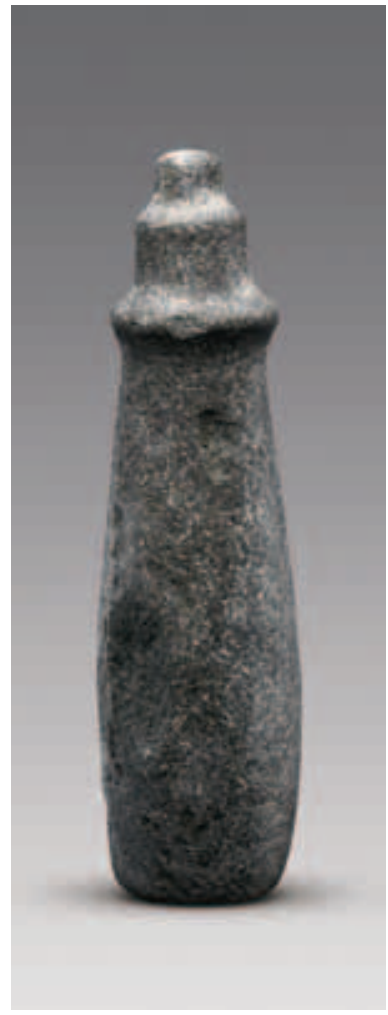

Figure 34 Stone pestle (F6:17).

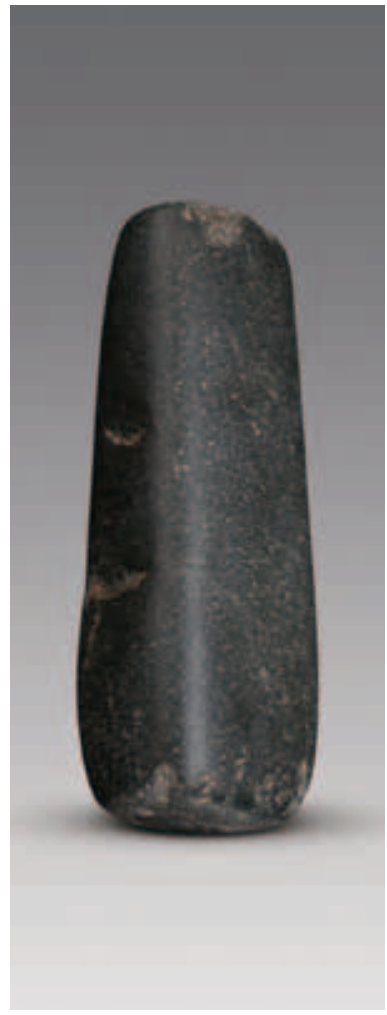

Figure 35 Stone pestle (F6:31).

Brought to you by | University of Oxford - Bodleian Libraries 
Shovel F11:2 is oval in shape with a perforation in the middle. It is made of polished stone with ground-down sides on both ends. It is $21.3 \mathrm{~cm}$ long, $17 \mathrm{~cm}$ wide, and $3.2 \mathrm{~cm}$ thick (Figure 36).

Adze F2H55:1 was made of a flat greenish cobble with one slightly wider end. It is $23 \mathrm{~cm}$ long, $18.5 \mathrm{~cm}$ wide, and $3.5 \mathrm{~cm}$ thick (Figure 37).

Staff head F7:1 was made of white marble. It is round with a hole in it (not drilled through). Its outer diameter is $6.5 \mathrm{~cm}$ with a hole diameter of $2.5 \mathrm{~cm}$ (Figure 38 ).

3. Bronze objects.

Bronze items include knives, cones, and mirrors.

Knife F6:20 has a straight handle and single-edged blade. The handle and blade are connected through a small circular hole. Both sides of the handle have symmetrically engraved thin lines, one of the lines being connected with the small hole. The knife is $8.9 \mathrm{~cm}$ long and $2.9 \mathrm{~cm}$ wide (Figure 39). T2 (3):1 has a straight handle and single-

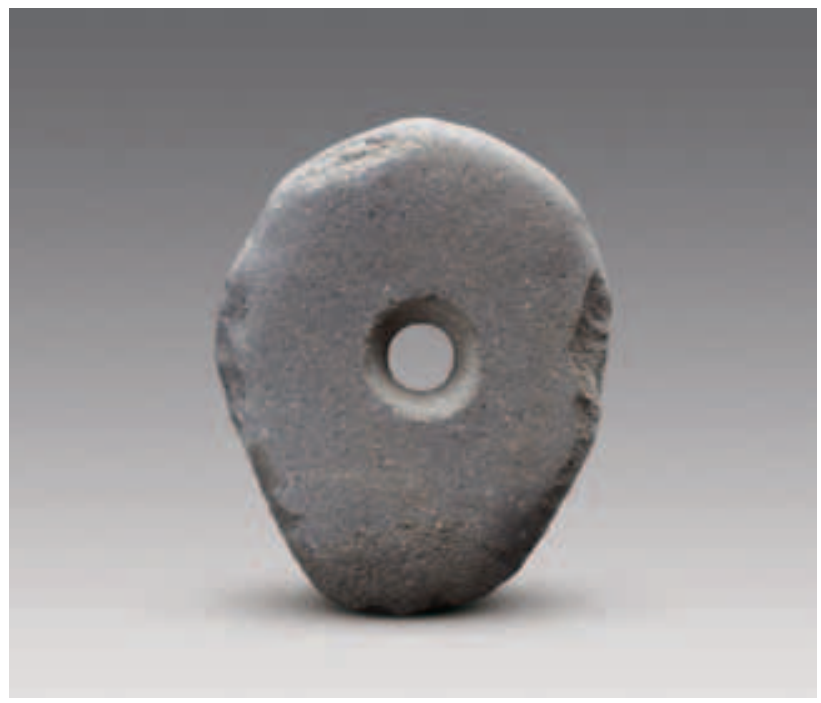

Figure 36 Stone shovel (F11:2).

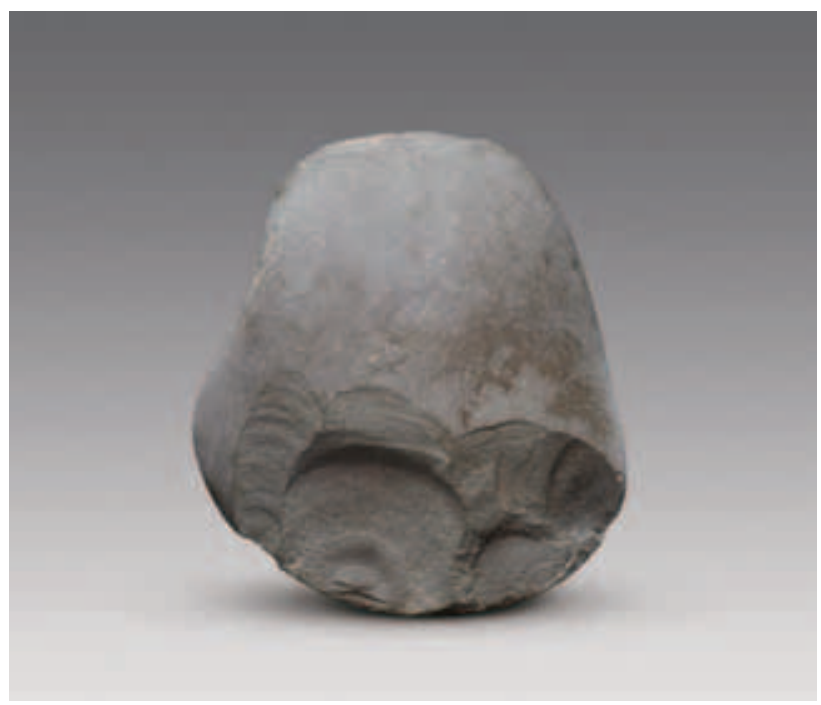

Figure 37 Stone adze (F2H55:1). edged blade as well. It is $15.8 \mathrm{~cm}$ long and the blade is $3 \mathrm{~cm}$ wide (Figure 40). T1 (2):1 has a straight ring handle and single-edged blade. The handle is decorated with net pattern. The knife is $21.3 \mathrm{~cm}$ long and the blade is $2.2 \mathrm{~cm}$ wide (Figure 41).

Mirror M49:1 was covered in rust and the item had been produced by casting. It was round and slightly thicker in the middle than at the margins. It had a short straight handle with a hole at the end. Both its faces were undecorated. It measures $9.4 \mathrm{~cm}$ in diameter and is $0.2 \mathrm{~cm}$ thick (Figure 42).

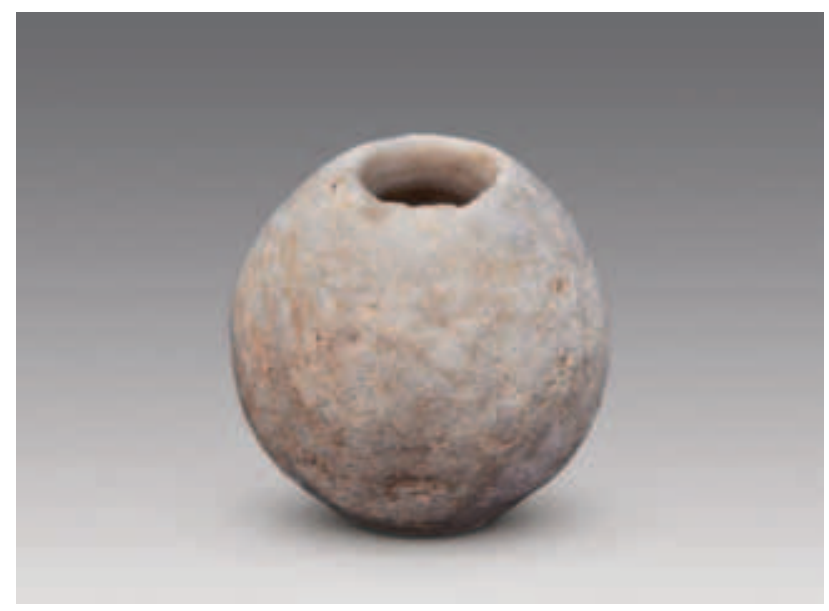

Figure 38 Stone staff head (F7:1).

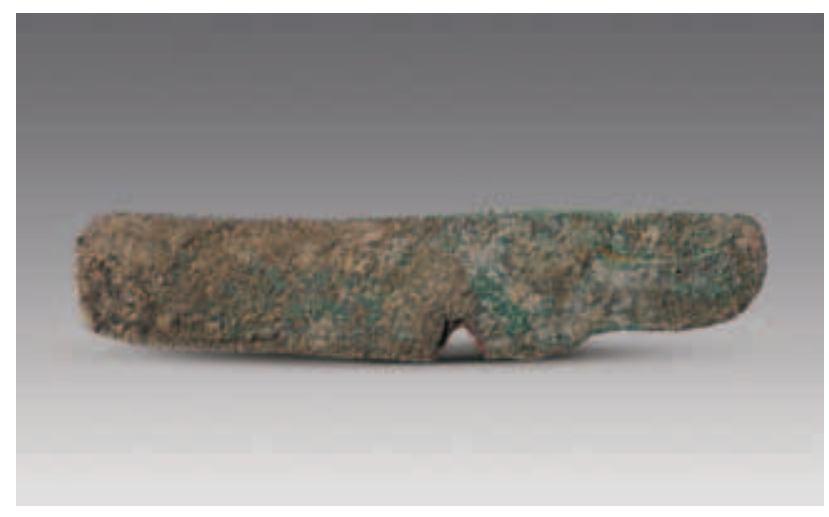

Figure 39 Bronze knife (F6:20).

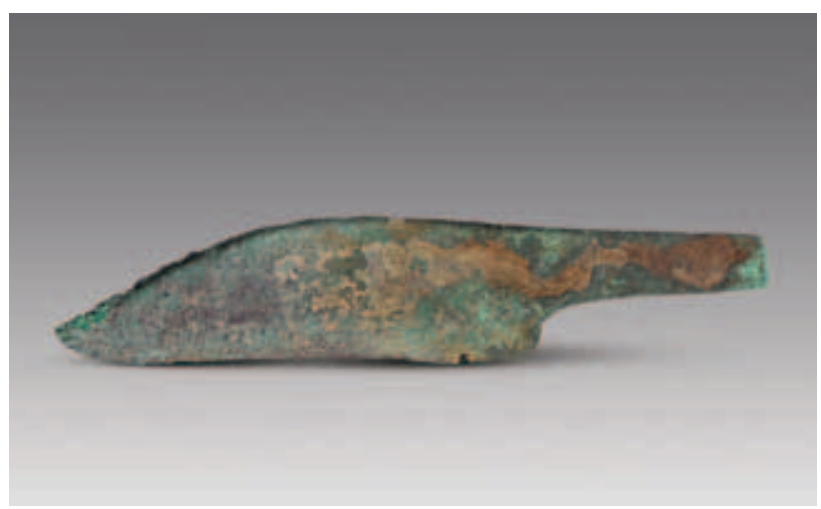

Figure 40 Bronze knife (T2 (3):1). 


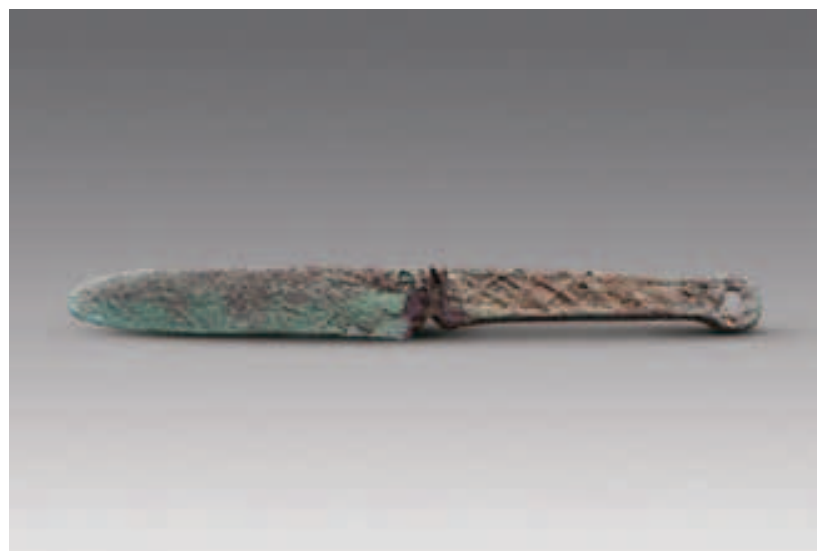

Figure 41 Bronze knife (T1 (2):1).

\section{Iron objects.}

There were three iron objects excavated from the southeastern and northeastern corners of T12 and the hearth of F10 respectively. They were severely corroded, small in size, and of irregular shape. Preliminary inspection suggests that they were produced by smelting and casting.

\section{Conclusion}

Through a comparative analysis of the features as well as ceramics, bronzes, and other items excavated at this site and the material excavated in recent years from Bronze Age burials in the Ili River Valley (Xinjiang 2012a, 2012b, 2014 and 2015), it becomes clear that there is a close cultural connection between the archaeological finds of Jartai Pass Site and the Andronovo finds of the Central Asian Bronze Age. Until now, the Ili River Valley has not yet furnished archaeological remains that would have been different from those of the early or late Bronze Age features attributed to the Andronovo Culture. The archaeological remains of Jartai Pass Site are complex and the excavated objects varied and rich in cultural connotations. The ${ }^{14} \mathrm{C}$ dates provided by Peking University and Beta Laboratory in the United States both suggest that the terminus post quem of the site is around $3600 \mathrm{BP}$, making this the largest and earliest Bronze Age site found in the Ili River Valley so far. The excavations and research conducted at this site will further our understanding of the Andronovo Culture and its development, help us explore the origin and culture context of the early Iron Age in the Ili region, allow us to push forward the task of establishing the archaeological cultural sequence of the Ili River Valley, and explore the archaeological remains and cultural contacts between the western Tianshan Mountains and the Eurasian steppes during the Bronze Age.

1. There are not many Bronze Age archaeological cultures that have been discovered in Xinjiang so far. The known ones include the Xiaohe Culture, the Tianshan Beilu Culture of the Hami Region, and the Xemirxek (Qiemu'erqieke) Culture of the Altai region, which are

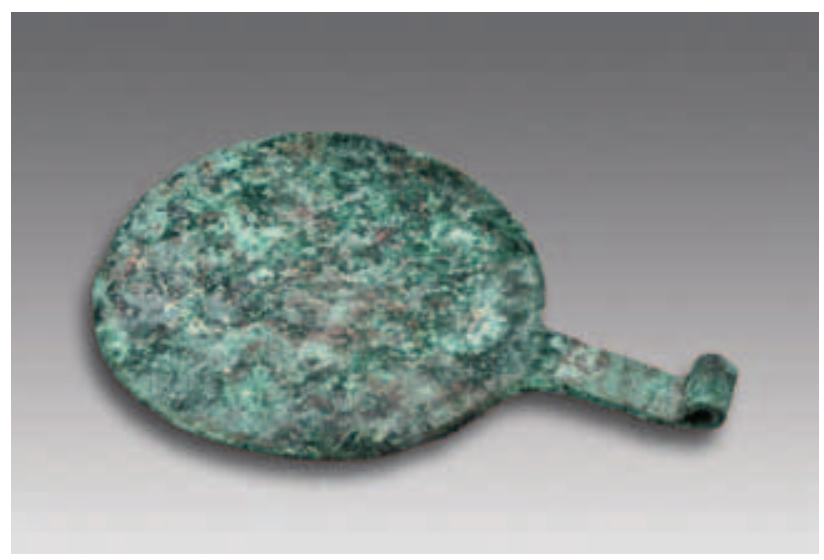

Figure 42 Bronze mirror (M49:1).

all mostly represented by burial material, the lack of settlement sites making it difficult to gain an in-depth understanding of the nature and origin of these cultures. The excavations conducted at Jartai Pass Site make it clear beyond the shadow of a doubt that there was a large Bronze Age settlement site that was connected with burials that have been excavated in the past, allowing us to gain a better understanding of the particularities of Bronze Age archaeological cultures in the Ili region. In particular, the site provides important data for organizing social structure, social development, and cultural evolution of that time period, filling a major blank in our knowledge of the Bronze Age settlement archaeology of the region.

2. In recent years, a considerable number of archaeological remains of the Andronovo Culture have been discovered on the three tributaries on the upper reaches of the Ili River, among them the Qongkök Site in the Kax River Basin (Liu 2011), Qarasu Site, Wutulan cemetery and sacrificial site (Xinjiang 2014a), the Chalger Site (Xinjiang 2014b), Tangbalesay Cemetery (Xinjiang 2012a), Ayousai Goukou Site in the Künes River Basin (Xinjiang 2013), and Koksu West Cemetery no. 2 in the Tekes River Valley (Xinjiang 2012b), but these sites are all very limited in scale and the burials and settlements are difficult to match up. The Jartai Pass Site has clear cultural layers, early Iron Age features clearly overlaying and cutting into late Bronze Age ones, as well as many other important discoveries. Furthermore, F6, F2, and other house features are very similar to the features previously excavated at Koksu West Cemetery no. 2 and the stone-cist burial group of Wutulan, both in structure, construction material, and craftsmanship. This discovery provides important evidence not only for the connection between settlements and burials in the Ili River Valley but also for the distribution and nature of the Andronovo Culture.

The Andronovo Culture of the grasslands of Central Asia had a strong influence on the western Tianshan region. The settlement and cemetery of Aduun Chuluu in Wenquan County in the western Tianshan region (Institute of Archaeology 2013) is very similar to the 
Jartai Pass Site in terms of date, and there are also strong similarities in location selection, scale, structure, layout, features, and unearthed objects. These findings provide important information for an in-depth understanding for the cultural contact and connection between Bronze Age archaeological cultures of the western Tianshan and the Eurasian steppe zone.

3. The Jartai Pass Site has also furnished the earliest evidence for the use of coal observed anywhere in the world, pushing its use back by more than 1000 years. A large number of coal blocks, coal ash, unexhausted coal pieces, and coal heaps were found at the site. This indicates that in 3600 BP people already fully understood the nature of coal and used it intensively. This understanding must have had a profound influence for the development of resource usage and production activities.

4. The bronze molds found at the Jartai Pass Site are the earliest pottery molds discovered so far in Xinjiang or indeed all of China. Additionally, the site furnished copper ores used as raw material, fragments of tuyere and crucible used for smelting, remnants of copper slag, small stone molds used for casting, remnants of furnace walls and the like testify to a certain scale of copper smelting and casting activities at the site. Additionally, three pieces of iron were unearthed, which are rather early evidence for iron production in Xinjiang and China as a whole. These findings are undoubtedly of great significance to the study of metallurgical archeology in China and provide new materials for the in-depth study of the metallurgical history of the Bronze Age in Xinjiang and even in Central Asia as a whole.

\section{References}

Institute of Archaeology, CASS 中国社会科学院考古研究 所 et al. 2013. 新疆温泉县阿敦乔鲁遗址与墓地 [The Aduun Chuluu Site and Cemetery in Wenquan (Arixang) County, Xinjiang]. Kaogu 考古 (Archaeology) 7:25-32.

Liu, Xuetang 刘学堂. 2011. 伊犁河上游史前考古新发现及 其初步研究 (On the new prehistoric discoveries in Upper Ili Valley). Xinjiang wenwu 新疆文物 (Cultural relics of Xinjiang) 1:84-107.

Xinjiang Cultural Relics and Archaeology Institute 新疆文
物考古研究所. 2013. 新源县阿尤赛沟口遗址考古发掘 简报 (The excavation of A'yousaigoukou Site in Xinyuan County). Xinjiang wenwu 2:4-10.

Xinjiang Cultural Relics and Archaeology Institute 新疆文 物考古研究所. 2014a. 尼勒克县乌吐兰墓地考古发掘 报告 (Excavation of Wutulan Cemetery of Nilka County). Xinjiang wenwu 1:36-57.

Xinjiang Cultural Relics and Archaeology Institute 新疆文 物考古研究所. 2014b. 尼勒克县恰勒格尔遗址考古发 掘简报 (Excavation of Qialegeer Site of Nilka County). Xinjiang wenwu 1:32-5.

Xinjiang Cultural Relics and Archaeology Institute 新疆文物 考古研究所. 2015. 2014 年尼勒克县乌吐兰墓地考古发 掘报告 (Excavation of Wutulan Cemetery, Nilka County). Xinjiang wenwu 2:4-17.

Xinjiang Institute of Cultural Relics and Archaeology 新疆文 物考古研究所. 2012a. 新疆伊犁尼勒克汤巴勒萨伊墓地 发掘简报 (The excavation of the Tangbalesay Cemetery in Nilka, Ili, Xinjiang). Wenwu文物 (Cultural relics) 5:13-22. Xinjiang Institute of Cultural Relics and Archaeology 新疆文 物考古研究所. 2012b. 新疆特克斯县阔克苏西 2 号墓 群的发掘 (The excavation of the Koksu West Cemetery No. 2 in Tekes County, Xinjiang). Kaogu 9:3-16.

\section{Postscript}

The samples collected at the bottom of houses F2, F3, and F6 of Phase I of Jartai Pass Site were radiocarbon dated by the AMS Laboratory of Peking University. F2 dates to $3195 \pm 35$ and $3285 \pm 30 \mathrm{BP}$, and $\mathrm{F} 3$ to $3275 \pm 30 \mathrm{BP}, \mathrm{F} 6$ to $3250 \pm 30 \mathrm{BP}$, and the calibrated date is about $3600 \mathrm{BP}$. M49 and M75 date to $2935 \pm 20$ BP and 2950 \pm 25 BP, i.e., about 3200-3100 BP. The samples collected at F2 and F5 were radiocarbon dated in the United States by Beta Laboratory. F2 dates to $3300 \pm 30 \mathrm{BP}$, and the calibrated date is about $3600-3500$ BP. Phase II represented by F5 is dated $2860 \pm 30 \mathrm{BP}$, and the calibrated date is about 3100 3000 BP (F5 intruding into F2). The team leader for the excavation is Qiurong Ruan 阮秋荣. The original report published in Kaogu 考古 (Archaeology) 2017.7:57-70 was coauthored by Qiurong Ruan and Yongqiang Wang 王永强. This English version is translated by Anke Hein 安可. 